
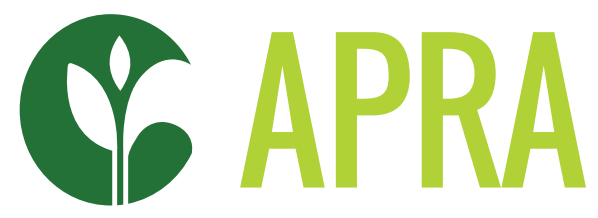

Agricultural Policy Research in Africa

\title{
THE DRIVERS OF MEDIUM-SCALE FARMS AND THE EMERGING SYNERGIES AND CONTRADICTIONS AMONG SOCIALLY DIFFERENTIATED FARMERS IN NORTHERN GHANA
}

Joseph A. Yaro, Ibrahim Wahab, Gloria Afful-Mensah, and Michael Ben Awenam 


\section{CONTENTS}

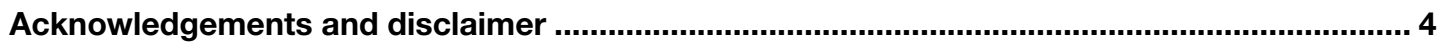

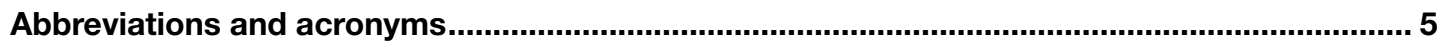

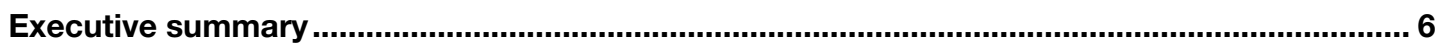

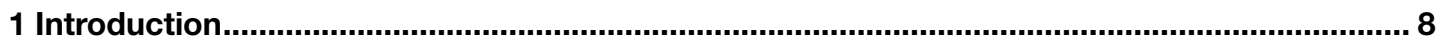

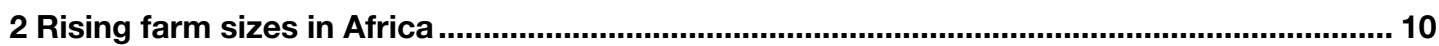

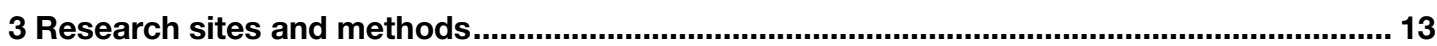

4 Farm size changes from years $2000-2020$ and their drivers ................................................ 16

4.1 Mechanisation: The major force for rising farm sizes ............................................... 17

4.2 Herbicides and weedicides as facilitators of farmland extensification............................. 18

4.3 Urban-based investor farmers and local rich farmers as catalysts for agricultural

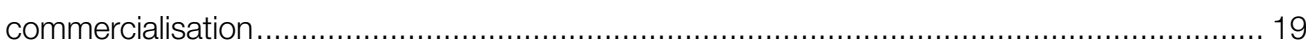

4.4 Markets: Increasing population and urbanisation creates demand for more food ............ 19

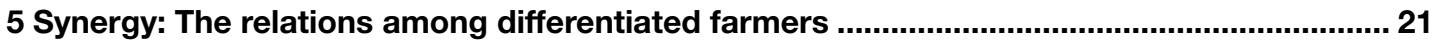

5.1 Labour-capital exchanges between the farmers ........................................................ 21

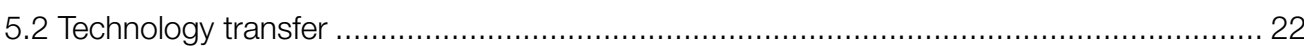

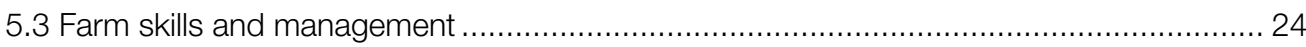

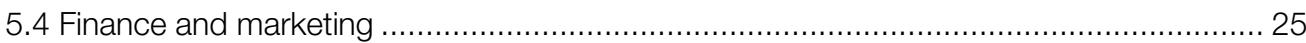

6 Contradictions: Losers and winners of the processes of rising farm sizes .......................... 27

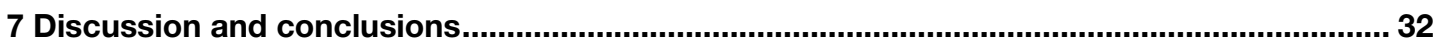

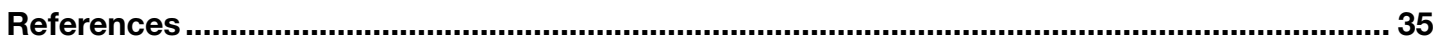

\section{List of tables}

Table 3.1: The number and categories of informants and main issues discussed ................. 15

Table 5.1: Labour exchanges between and amongst scales of operation (in percentages) .... 21

Table 5.2: Source of technology transfer among different scales of operation

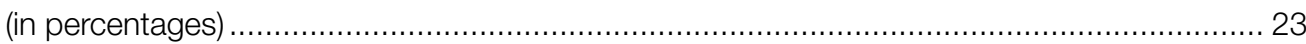

Table 5.3: Farm skills and management relations among farmers (in percentages) ................ 24

Table 6.1: Difficulty/ease of access to and/or use of farmlands (in percentages) ................... 27

Table 6.2: Standard of living of different farm scales and gender

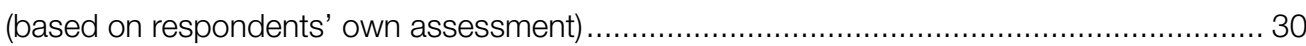

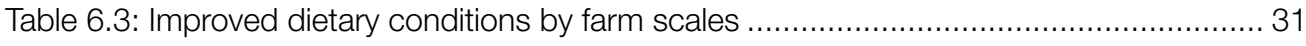

Table 6.4: Improved dietary conditions by location (region) ............................................... 31 


\section{List of figures}

Figure 3.1: Map of Karaga district showing the research communities .............................. 13

Figure 3.2: Map of Builsa District showing the research communities................................. 14

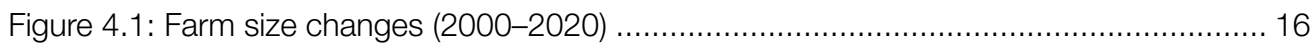

Figure 4.2: A sample of the main farm mechanisation equipment....................................... 17 


\section{AGKNOWLEDGEMENTS AND DISCLAIMER}

We thank the chiefs and people of the Karaga traditional area and the Builsa communities for their support in providing responses to our questions, showing us their fields and detailing the changes in the agricultural history of their communities and districts.

Joseph Awetori Yaro is Professor in the Department of Geography and Resource Development, University of Ghana. Ibrahim Wahab is a Postdoc in the Department of Human Geography, Lund University, Sweden. Gloria Afful-Mensah is an Economist with the Department of Economics, University of Ghana. Michael Ben Awenam is Human Geographer with the Department of Geography and Resource Development, University of Ghana.

This working paper is funded with UK aid from the UK government (Foreign, Commonwealth \& Development Office - FCDO, formerly DFID). The opinions are the authors and do not necessarily reflect the views or policies of IDS or the UK government. 


\title{
ABBREVIATIONS AND ACRONYMS
}

\author{
FGD \\ focus group discussion \\ NGO \\ non-governmental organisation \\ SSA \\ sub-Saharan Africa
}




\section{EXECUTIVE SUMMMARY}

Since the turn of the century, agriculture in sub-Saharan Africa (SSA) has been undergoing rapid transformation. Ghana is experiencing an agrarian revolution with increasing farmland sizes, increased mechanisation of production and external input usage, and high levels of commercialisation. In this paper we show the growth of farm sizes, the major drivers of increasing farm sizes, and emerging relations between different scales of farmers. The paper discusses the synergies and contradictions emerging from the processes of agricultural commercialisation in the context of rising farmland sizes and the implications for different social groups. The study was conducted in two districts in the north of Ghana using a mixed-method approach triangulating qualitative, quantitative, farm mapping and historical information.

Most small-scale farmers from two decades ago have graduated (stepped up) into lower-medium-scale farmers cultivating between 4-20ha. They form the bulk of farmers in the districts whose production in aggregate accounts for the bulk of total production. There is notable decline in the small-scale farming (27 per cent of men), although 60 per cent women are left behind in this group. The percentage of lower-mediumscale farmers has more than doubled between 2000 and 2020 , while that of small-scale has declined by almost half - from 76.4 per cent in 2000 to 36.3 per cent in 2020. Only 7.5 per cent of farmers are found in the upper-medium-scale group cultivating between 51 and 100 acres. All large-scale farmers are male, and their number has been stable in the last 15 years. The upper-medium-scale and large-scale farmers are composed of chiefs, migrants (urban farmers and rich farmers from land-stressed communities) and the local rich farmers. Most large-scale farmers have stepped in, with capital from other businesses and with less skills in farming compared to the medium-scale group.

The most important drivers of farm size increases, and agricultural commercialisation include mechanisation, weedicide/herbicides, improved seeds, urban markets or increasing demand for food, and infrastructure. The availability of land in the area with flexible noncommercialised land tenure systems form the basis of past and current farm expansions. These are mediated by the positive role of the state over the years in modernising agriculture through interventions ranging from direct engagement in production in the 1960s; support for modern large farmers and developing farm infrastructure in the 1970s; liberalised markets in the 1980s; return to poverty reduction using markets and state interventions in the 1990s; and, currently, a reformulated array of old and new strategies under the auspices of the African Union. The processes of farm expansion follow from the historical conditions of agrarian change, which began in the postindependence era.

This study fills an important gap by teasing out the relations among small, medium, and large farmers, which are hypothesised in different directions in the literature without a clear explanation of the nuances and local specificities. The relations between the different categories of farmers can be described as both synergistic and contradictory. On the synergistic side, there have been positive relations between smaller and bigger farmers through reciprocal exchanges of labour and local knowledge for capital and new technologies. Larger farmers have made mechanisation services available to their smaller counterparts, thereby alleviating the general labour problems that constrained smaller farms. The creation of jobs by upper-medium and large farmers has created a source of capital for investing in smaller farms and meeting food needs during periods of stress. Meanwhile, larger farmers with limited experience in farming are benefitting from the advice of small farmers in the choice of fields, crops, and farming practices. Also, the political power of richer farmers, especially urban-based politicians, businesspeople and bureaucrats, is often used to influence the development of infrastructure and subsidy regimes for agro-inputs.

However, the contradictions of the increasing farm sizes and modernisation of agriculture creates losers and winners. First, land is allocated to richer and larger farmers who provide more incentives to the custodians of land, such as mechanisation services, cash, and inputs. Second, labour of poorer and smaller farmers is used by the larger, richer ones to the detriment of the former, hence big farmers benefit more from 
their relations with smaller farmers through the exploitation of their labour and extraction of rents from mechanisation services and loans. Third, there is an increasing dependence on agro-inputs and, therefore, global networks with the enrichment of these input dealers and manufacturers, as local nature-based ecological alternatives are abandoned. Fourth, there is a reorientation of traditional relations in favour of a more commercialised non-communitarian one. Fifth, women and youth are losing out in the growing opportunities due to financial and patriarchal traditional rules.

Generally, theincreasing commercialisationofagriculture in the districts is welcome as improvements in the form of increasing incomes, food and nutritional security, and general wellbeing is reported by the respondents. A combination of agricultural modernisation initiatives, together with a basic need ethos, seems to be responsible for this positive development. To propel the ongoing agricultural revolution in northern Ghana, it is necessary to enhance and support beneficial relations among different categories of farmers, while reducing the contradictions and tensions emerging from these relations. The state needs to revise its role in facilitating the availability of technological inputs to farmers through smart subsidies; building implement fabrication training centres and linking local fabricators with more advanced counterparts in a South-South cooperation framework; deal with mechanisms to regulate land allocation and subsequent security; improve innovation diffusion of both local traditional and modern practices through extension services; and tackle environmental pollution due to increasing agrochemical use 


\section{INTRODUCTION}

Ghana has witnessed increases in the cultivated area for all major crops between 2006 and 2015 (MoFA, 2015). An organic transformation in farmland is happening in Ghana where a significant proportion, about 70 per cent, of the medium-scale farmers started out as small-scale farmers (Jayne et al., 2014). In the northern parts of Ghana, it is noted that farm sizes are gradually increasing with a shift from small farms to a mix of medium- and large-scale farms (Houssou et al., 2016). Associated with the changes in farm sizes are changes in crops grown over time, with observed disappearance and emergence of crops grown in some parts of the guinea savannah (Houssou et al., 2016). The northern parts of Ghana are now among the top producers of major crops such as cowpea, maize and rice, which is an indication of the commercial ethos imbibed by the northern farmer over the years. The transformations in the agrarian landscape are responses to multiple incentives and pressures, and have consequences for different categories of people including the forging of new relationships with the actors involved. The marginalisation of the poor peasantry in favour of richer households and outsiders is notable. The perceived opportunities that arise from the process, of which the poor can take advantage, need critical examination. The relationships between emerging larger and smaller farmers and the range of actors on the agricultural value chain also need further interrogation. Critically, the changes in traditional institutions, norms and values in these societies around social reproduction because of rising farm sizes and commercialised tendencies needs examination. Who are the winners and losers of these processes, and what political economy processes and factors are responsible? This paper attempts to provide answers to these broader questions using the case of two districts in northern Ghana.

A wide range of farm sizes qualify as medium-scale farms, but have different peculiarities and actors that must be disaggregated in order to grasp the nuances in drivers, actors involved and their effects on general agrarian change and communities' wellbeing. The generalised effects on poverty reduction and employment for all people and the local economy, in terms of not only growth in agriculture but also the diversification of the economy, are important. The relationships between smallholders and medium-scale farmers, ${ }^{1}$ which are hypothesised as either mutual or antagonistic, need good evidence. The outcomes of these relationships and changing farm structures are important for policymakers and local development partners promoting the commercialisation and modernisation of agriculture. Similarly, the position of women in the changing agrarian landscape requires renewed interest to ascertain their participation, benefits and challenges. In this paper we seek to show the synergies and complementarities among the different scales of farmers, and the contradictions and emerging challenges. Of great interest is the role of investor farmers and urban-based farmers. The proportion of national landholding greater than 20 ha held by urban households increased from 36.9 per cent in 2008 to 42.7 per cent in 2014 in Ghana (Jayne et al., 2019) showing the growing interest and a come-back of urban capital owners into agriculture, similar to the trends in the 1970s (Konings, 1984).

An important postulation is that investor farmers with enormous capital, technology, and political backing, but with little experience in farming, often make more costly mistakes, especially with regards to farming decisions that require enormous local knowledge and experience, compared to the small-scale farmers who have upscaled into medium-scale operators with years of vast experiences. However, literature attests that medium-scale farms are highly educated, and have high incomes, enabling them to afford productivityenhancing farm inputs and interpret messages from extension agents (Omotilewa et al., 2021). The two however, possess unique qualities which, when harnessed well through the right policies and strategies, may lead to local and national beneficial inclusive commercialised agriculture.

$1 \quad$ In this paper, we categorise farm sizes into those less than 10 acres (4ha) in size as small, 11-50 acres (4.1-20.5ha) as lower-medium, 51-100 acres (20.6-40.5ha) as upper-medium, and those above 100 acres (40.5ha) as large farms. While similar studies often lump farms between 10 and 100 acres as medium scale, we are of the view that disaggregating this group further brings to the fore some important nuances. 
This paper presents the trends in rising farmland sizes briefly, before discussing the drivers for the rise of medium-scale farms. The second part discusses the relations between small-, mediumand large-scale farmers, showing the synergies and contradictions emerging from the processes of agricultural commercialisation in the context of rising farmland sizes. The analysis is presented showing the differences in farmer experiences and implications for different social and gender groups. 


\section{RISING FARM SIZES IN AFRICA}

Since the turn of the century, agriculture in SSA has been undergoing rapid and far-reaching transformation. A significant part of this transformation involves major changes in farmland ownership, as well as shifts in the dominance of farming scales from small- to mediumand large-scale farms. An important stylised fact on agriculture in SSA, particularly in the last two decades, is thus, general increases in farm sizes. A multiplicity of studies, including Deininger and Byerlee (2012), Jayne et al. (2016), Lay et al. (2018) and Jayne et al. (2019), across a number of SSA countries affirm this development. This new trajectory detracts from earlier trends in farm sizes, whereby average farm sizes decreased in most low- and lower-middle-income countries between 1960 and 2000 (Lowder, Skoet and Raney, 2016). Two key demographic processes rising rural population densities (Masters et al., 2013) and the tendency for most people to maintain farmland ownership irrespective of their primary source of employment - create a situation where an evolution towards smaller farm sizes was inevitable (Jayne et al., 2016). However, within the last two decades, several studies across many countries on the continent, show evidence of a change in the trend towards rising, rather than shrinking, farm sizes. Jayne et al. (2016) attribute these new dynamics in African farm size distribution to four main factors: changes in land acquisition regimes, with rapid rise of land markets; hikes in global food prices which have fuelled demand in farmlands; agricultural policy reforms, which started in the 1980s and 90s but whose full effects remained dormant until the 2000s; and the increasing power of farm lobbies within the context of increasing democratisation and multiparty politics which gave voice to farmer unions and other powerful groups.

There is a general reduction of the share of land under small-scale cultivation and the corollary increases in those under medium-scale farming. This can be exemplified across several countries in western, eastern and southern Africa. Data from nationallyrepresentative surveys from four countries (Ghana, Kenya, Tanzania and Zambia), show that the share of land under small-scale farming - which they define as between 0 and 5 ha - is experiencing a declining trajectory in all countries except Kenya, while mediumscale farms, which control roughly 32 per cent of total farmland in Ghana, 20 per cent in Kenya, 39 per cent in Tanzania and 50 per cent in Zambia, are not only increasing in proportion, but also in absolute numbers (Jayne et al., 2016). Medium- and large-scale farms thus increasingly control a substantial proportion of farmland in Africa (Deininger and Byerlee 2012, Chamberlin and Jayne, 2020) and given current trends, will soon become the dominant scale of farming in many African countries (Jayne et al., 2016). The peculiar case of Kenya in this study is attributed to the absolute dominance of small-farm sizes and relative land scarcity in that country.

It is important to point out that these changes are not occurring uniformly across all countries on the continent. With estimates suggesting that as much as 52 per cent of the world's remaining arable land is located in Africa (Deininger et al., 2011), the continent is typically characterised as land-abundant. There is, however substantial regional, national, and even subnational heterogeneity in farmland availability, with most of the available land being concentrated in relatively few countries (Jayne, Chamberlin and Headey, 2014). The implication of this is that the ongoing process of rising farm sizes in Africa is spatially heterogeneous with some regions, under demographic pressure, seeing increasing farm sizes, while others are seeing stable or even shrinking farm sizes. That is, on the one hand, the share of land under medium-scale cultivation is not rising in densely populated countries, such as Kenya, Rwanda and Uganda, where relative land scarcity is slowing the pace of medium-scale farm acquisitions and developments. On the other hand, in countries with substantial unutilised land, such as Tanzania and Zambia, as well as the northern parts of Ghana and Nigeria, these increases are significant.

Northern Ghana plays a significant role in the phenomenon of rising farm sizes in Ghana. A number of historical and socioeconomic factors conspired to ensure vast tracts of land and lower levels of rural population density, which created relative land abundance (Songsore, 1979; Konings, 1981; Kasanga, 1995). Medium- and large-scale farms are historically known for their reliance on the abundance of land and labour (Smalley, 2013) and northern Ghana is noted for both. The country is thus also undergoing 
this transformation in farm structure that is occurring in other relatively land-abundant countries on the continent. Trend analysis of data from the Ghana Living Standards Survey conducted in 1992/93 and 2012/13 supports this assertion. From this dataset, Jayne et al. (2016) find that while the number of farms in absolute terms increased in all farm categories between 1992 and 2012, the change is more significant for larger farm sizes than smaller ones. For example, while farms between 0 and 5 ha in size increased by only 37 per cent between 1992 and 2012, those in the 10-20ha and 20-100ha ranges increased by 238 per cent and 314 per cent, respectively, across the country. Also interesting is the proportion of operated farmland under the different scales of farm. The trend shows significant decreases for the 0-5ha range from 1992 to 2005 but an increasing trend for all other categories, with the most significant increases occurring within the 10-20ha and 20-100ha range (Jayne et al., 2016).

A consequence of the rapid rise in farm sizes on the continent is the concentration of landholdings in some countries, with the Gini coefficients of landholdings rising in Ghana from 0.52 in 1992 to 0.65 in 2005, in Kenya from 0.51 in 1994 to 0.55 in 2006, and in Zambia from 0.42 in 2001 to 0.49 in 2012 (Jayne et al., 2014). This indicates an increasing concentration of land under the control of a few wealthy people in some land-scarce countries in Africa. So, who are these people that are participating and benefitting from these land acquisitions and driving the rapid rise in mediumscale farms? Life history surveys show that they are predominantly men whose primary employment is in non-farm sectors, generally lived and continue to live in urban centres, are usually in government or at least employed in the public sector, and who use wealth acquired from other sources than farming to acquire large lands in their middle ages in rural areas (Jayne, Chamberlin and Headey, 2014; Sitko and Chamberlin, 2016; Chamberlin and Jayne, 2020).

In a survey of three countries, the above profile fits about 60 per cent and 58 per cent of the sampled mediumscale farmers in Kenya and Zambia, respectively. Ghana is the only exception, where a significant proportion (70 per cent) of the medium-scale farmers started out as small-scale farmers (Jayne et al., 2014). Thus, while a large proportion of medium-scale farms in Ghana and also in Nigeria stepped up (Jayne et al., 2014; Muyanga et al., 2019), the majority of them in Kenya and Zambia can be described as having stepped into farming. In corroborating this trend, a separate study using the nationally representative Demographic and Health Survey dataset on six countries - Ghana, Kenya, Malawi, Rwanda, Tanzania and Zambia - shows that urban households own between 5 and 35 per cent of total agriculture land, and this share is continuously rising (Jayne et al., 2016). Even more interesting is the trend in the ownership of large farmlands by urban households. The proportion of national landholding greater than 20 ha held by urban households increased from 36.9 per cent, in 2008, to 42.7 per cent in 2014 in Ghana, from 34.3 per cent in 2009 to 41.2 per cent in 2014 in Kenya, from 17.2 per cent in 2005 to 78.9 per cent in 2010 in Tanzania, and from 21.7 per cent in 2007 to 29.3 per cent in 2014 in Zambia (Jayne et al., 2019). It is interesting to note that most people classified as urban today in Ghana were rural dwellers two decades ago, but due to the processes of periurbanisation, have been overrun by the rapidly growing towns, thereby driving a substantial proportion of the population that cannot be absorbed by the peri-urban economy into land abundant rural areas for farming as either commuters or seasonal migrants (Yaro, 2012).

Knowing the kind of people driving these rising farm sizes is important to the extent that the scale and distribution of farmland holdings tend to influence local demand patterns, factor markets, and concomitant effects on agricultural growth (Johnston and Mellor, 1961; Chamberlin and Jayne, 2020). Smallholders are known to consume and spend more of their money in the local rural economy compared to their larger, urban-based counterparts, and thus more significantly stimulate forward and backward linkage between the farm and non-farm sectors (Mellor, 1976). That is, farmers who started farming as smallholders and stepped up into medium-scale status would have a better effect on the rural economy than medium-scale farmers who have stepped into the venture, particularly where the latter is primarily urban-based. Also important is the relationship between medium-scale farmers and their small-scale counterparts. Not only do smallholder households benefit from being located close to large farms (Lay et al., 2018; Burke, Jayne and Sitko, 2020), but also the benefits that accrue to the former are maximised if the two categories share common social, ethnic or familial connections (Chamberlin and Jayne, 2020). Similarly, Liverpool-Tasie et al. (2020) find significant positive welfare effects for small-scale farmers that engage with medium-scale farmers in their communities. Thus, in the context where the dominant class of medium- and large-scale farmers are wealthy, urban-based elites who maintain weak connections with the rural economy, the benefits that ought to come with such growth in agriculture would be curtailed. An important lesson from Asia and Latin America is that a more egalitarian land distribution pattern that allows for stepping up tends to generate more broadly based agricultural growth, higher rates of economic growth, 
and have relatively stronger poverty-reducing effects than when farmland is concentrated in the hands of a few wealthy people who are primarily resident outside the rural areas. The trends and dynamics of the agricultural transformations in Africa may show a similar pattern but its character, constituents, historical antecedents, and consequences are unique and require unravelling to avoid inimical policy prescriptions.

Historically, the agrarian political economy in Ghana has tended to go through a cyclical pattern of decline and regrowth in consonance with policies that have had differing impacts on agricultural development. Prior to the colonial era, subsistence agriculture dominated the agricultural landscape. With colonisation came the introduction of commercial ethos in agriculture. The plantation system, mainly of oil palm, met with limited success largely due to conflicts between and among the various ethnic groups, as well as disputes over territorial expansion among the colonialists (Yaro, Teye and Torvikey 2018). Plantation agriculture became increasingly more successful as cocoa, coffee and cotton became important export crops. The colonial economy was export-oriented and generally geared towards the production and export of produce required by industries in the metropole. This export orientation laid the foundation for the unequal spatial development of the colony, with the northern territories being the least developed (Sutton, 1989). In all of these, there was continuous support for small-scale farms due, in part, to the colonialists' apprehension that extensive land acquisitions for plantations could alienate the peasants, disrupt the well-established export system, and catalyse local opposition to the colonial system (Gyasi, 1996) even though some efforts were put into commercialising agriculture towards the end of the colonial era. Post-independence, there was a significant shift in agricultural policy towards a socialist model that favoured the establishment of large-scale state farms, with the view that small-scale agriculture was not easily amenable to modernisation (Dickson, 1968). By the time of the 1966 coup d'état, hundreds of state and cooperative farms had been established to produce bananas, cashews, fruits, groundnuts, maize, millets, rice, sorghums, sugarcanes, and yams, in addition to the already well-established cash crops - cotton, oil palms, rubber, and tobacco (Due, 1969). These new enterprises collapsed almost immediately after the regime's demise, due to challenges such as capital constraints, political interference, and poor planning and management.

Renewed efforts were made by the state to reinvigorate agriculture in the 1970s. A major policy that benefitted agriculture in the northern parts of Ghana was the 'Operation Feed Yourself' campaign, which focused on developing large-scale food production systems through governmental support to private individuals in the form of agro-inputs, such as improved seeds and mechanisation tools including tractors and combine harvesters (Vercillo and Hird-Younger, 2019). Continuous economic challenges led to the adoption of the Structural Adjustment Programmes and later, the Economic Recovery Programmes in the late 1970s and 80s. These programmes were essentially geared towards further liberalisation and export-reorientation of the economy, with a view to reversing inflationary trends and correcting the balance of payment problems. While policies such as the devaluation of the national currency initially drove shifts in the dominant sources of food supply from import to domestic sources, which in turn contributed to substantial growth in farm sizes (Braimoh, 2009), the programme also entailed the scaling back of the state in terms of subsidies and credit-support schemes for agro-inputs. This had adverse effects on agricultural development as aspiring agricultural entrepreneurs moved away from large-scale food production and towards investing in the plantation development of exotic fruits for exports (Amanor and Pabi, 2007). The net effect of these policies and programmes was the improved integration of Ghanaian farmers into the global value chains, even though there continues to be vacillations in policy between state- and private sector-driven agricultural development. These trends continued in the 1990s and 2000s, with the recent Planting for Food and Jobs programme in 2017 exemplifying this uncertainty. Agriculture investment in Ghana, thus, continues to be profitable, given the political economy of state support for an impoverished countryside in a laissez-faire neoliberal policy environment against the backdrop of high and rising prices for food (Yaro, Teye and Torvikey, 2018). 


\section{RESEARCH SITES AND METHODS}

The study sites are located in two districts with vast lands and a history of commercial farming; the Builsa South District of the Upper East region and the Karaga District of Northern Region. The communities in the Builsa South District included Gbedembilisi, Uwasi and Weisi, with substantial valleys, uplands and riverine plains for rice, cowpea and maize production, respectively. The study communities in the Karaga District included Maligunayili, Nyong and Tamaligu, where huge uplands and valleys are popular for growing groundnuts, soya bean, maize, and rice. Figures 3.1 and 3.2 are maps showing the districts and locations of the respective study villages. The two locations are known to be migrant-receiving areas with a wide variety of investor farmers and agricultural traders. The two districts are endowed with generally abundant farmlands with largely fertile soils. The districts have relatively good roads, which are passable for most of the year, and have very active local markets. Finally, they both benefit from above-average level of service from mechanisation and financial services as well as government programmes for agriculture. The Builsa area has a long history of commercial farming while that of Karaga is relatively recent, following the opening of the roads and the invasion of farmers from the densely populated Tamale areas where soils require huge doses of fertiliser to guarantee average yields. These provide opportunities to interrogate the drivers of the increases in farm sizes being witnessed in recent times.

This study employed a mix-method strategy, involving qualitative and quantitative approaches to capture the detailed nuances from the perspective of actors. Table 3.1 below gives a breakdown of the number of informants interviewed in both study districts, as well as the main issues that were discussed.

This assures us of both breadth and depth in our construction of the lived lives of the people, and

\section{Figure 3.1: Map of Karaga District showing research communities}

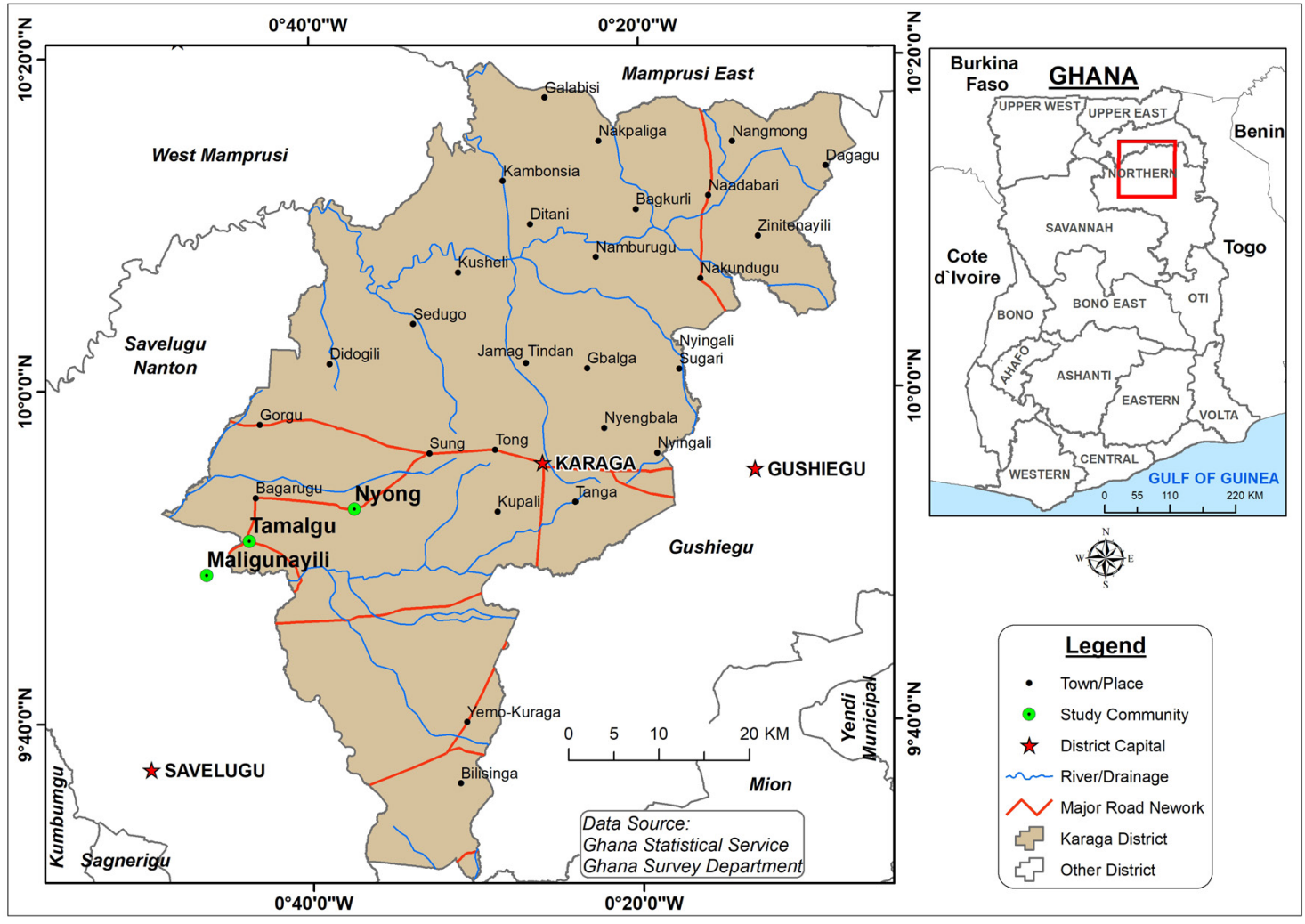

Source: ( Ghana Statistical Services, adapted by authors 
characterising the phenomenon of medium-scale farm changes and their socio-economic consequences for men and women. The methods employed included: a quantitative survey; life histories; farmer in-depth interviews; expert interviews; and focus group discussions (FGDs).

Figure 3.2: Map of Builsa South District showing the research communities

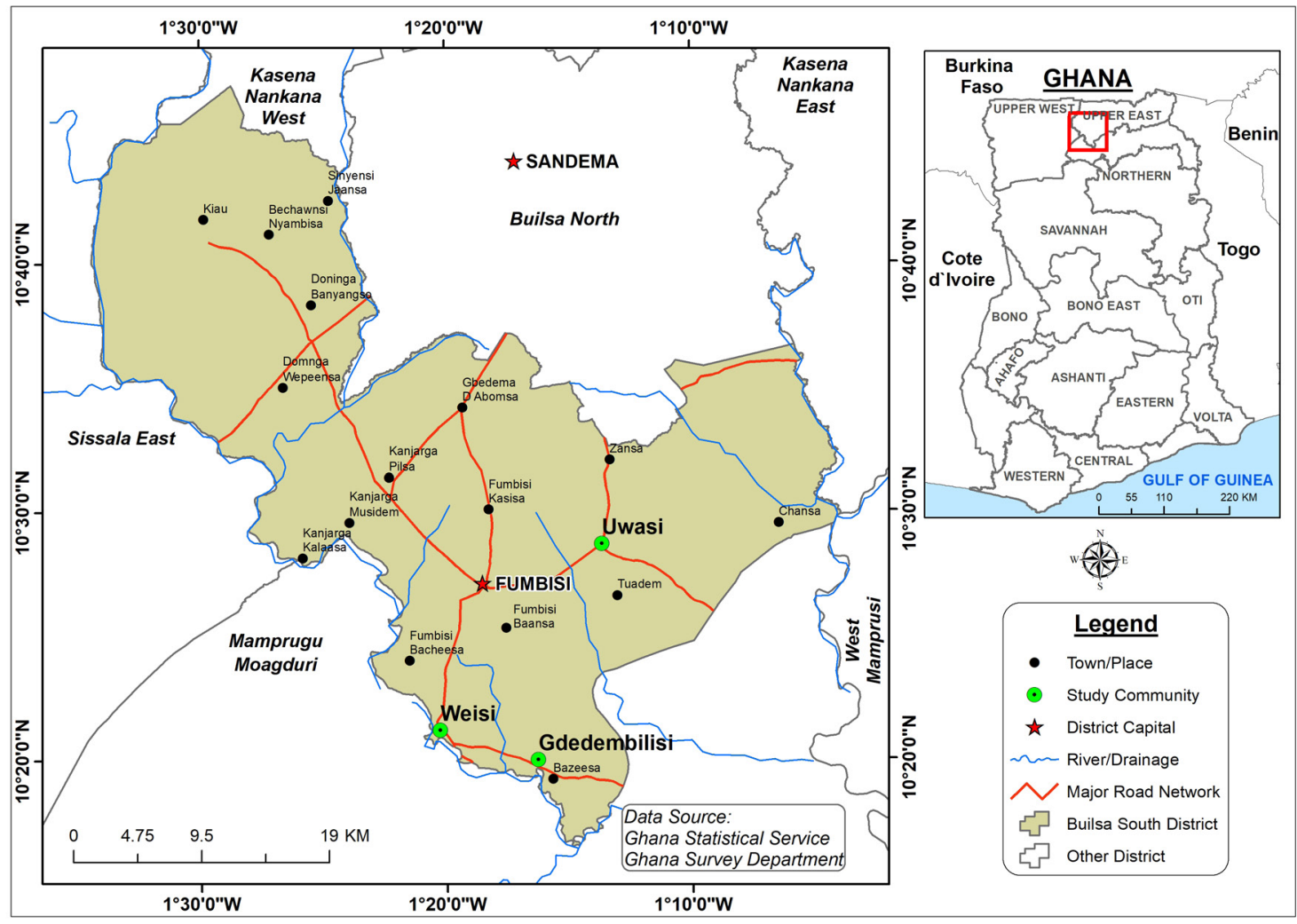

Source: (C) Ghana Statistical Services, adapted by authors 
Table 3.1: The number and categories of informants and main issues discussed

\begin{tabular}{|c|c|c|}
\hline $\begin{array}{l}\text { Category of } \\
\text { informants }\end{array}$ & $\begin{array}{l}\text { Number of } \\
\text { informants }\end{array}$ & Main issues discussed \\
\hline Life histories & 8 & $\begin{array}{l}\text { Targeted at elderly farmers to elicit data on farm changes that have occurred in } \\
\text { their lifetime: farm sizes, labour dynamics, land acquisition, crop changes and their } \\
\text { perspectives on current happenings }\end{array}$ \\
\hline $\begin{array}{l}\text { In-depth interviews - } \\
\text { Small-scale farmers }\end{array}$ & 8 & $\begin{array}{l}\text { Farmland, labour, and capital accessibility, inputs use, marketing dynamics, } \\
\text { relationship to bigger farmers, and specific challenges they are confronted with. }\end{array}$ \\
\hline $\begin{array}{l}\text { In-depth interviews } \\
\text { - Medium-scale } \\
\text { farmers }\end{array}$ & 8 & $\begin{array}{l}\text { Farmland, labour, and capital accessibility, input-use levels, mode of marketing } \\
\text { farm produce, relationship to other farmer categories, motivations for increasing } \\
\text { scale/venturing into farming, and specific challenges they are confronted with. }\end{array}$ \\
\hline $\begin{array}{l}\text { In-depth interviews - } \\
\text { Large-scale farmers }\end{array}$ & 4 & $\begin{array}{l}\text { Farmland, labour, and capital accessibility, input-use levels, mode of marketing } \\
\text { farm produce, relationship to smaller farmers, and macro and micro drivers of } \\
\text { farm size increases. }\end{array}$ \\
\hline $\begin{array}{l}\text { In-depth interviews } \\
\text { - Urban-based/ } \\
\text { investor farmers }\end{array}$ & 6 & $\begin{array}{l}\text { Motivations for going into farming, attraction of districts, government support, } \\
\text { equipment owned, labour/personal dynamics, both positive and negative } \\
\text { implications of their presence on local community }\end{array}$ \\
\hline $\begin{array}{l}\text { In-depth interviews - } \\
\text { Tractor operators }\end{array}$ & 2 & $\begin{array}{l}\text { Employment conditions with large-scale/investor farmers and terms of } \\
\text { engagement with other farmer categories. }\end{array}$ \\
\hline $\begin{array}{l}\text { In-depth interviews - } \\
\text { Labourers }\end{array}$ & 4 & $\begin{array}{l}\text { Terms of engagement/employment, casual, permanent, mode of payment - cash } \\
\text { or produce or combination etc. }\end{array}$ \\
\hline $\begin{array}{l}\text { Focus group } \\
\text { discussions }\end{array}$ & 4 & $\begin{array}{l}\text { Land access arrangement, main commercial crops, farm size trajectories over the } \\
\text { past decades, technology use, changes that are occurring in terms of tasks and } \\
\text { opportunities between men and women, relationship between various categories } \\
\text { of farmers, and food security situation of the years. }\end{array}$ \\
\hline $\begin{array}{l}\text { Expert interview - } \\
\text { Chiefs and Earth } \\
\text { Priests }\end{array}$ & 4 & $\begin{array}{l}\text { History of community, land control, access conditions for indigenes and migrants, } \\
\text { land disputes, main actors of farm size increases, disposition towards urban- } \\
\text { based investor farmers. }\end{array}$ \\
\hline $\begin{array}{l}\text { Expert interview - } \\
\text { District agriculture } \\
\text { officer }\end{array}$ & 2 & $\begin{array}{l}\text { Main farm actors in the district, nature of their farming activities, category of } \\
\text { farmers increasing their farm sizes, drivers of this process, and specific support } \\
\text { initiatives. }\end{array}$ \\
\hline $\begin{array}{l}\text { Expert interview } \\
\text { - Rural banks/ } \\
\text { microcredit } \\
\text { companies }\end{array}$ & 2 & $\begin{array}{l}\text { Support for farmers, main categories of farmers supported, quantum of loans } \\
\text { given, periods of servicing, interest rates and trajectories of support for farming. }\end{array}$ \\
\hline $\begin{array}{l}\text { Survey - } \\
\text { Questionnaires }\end{array}$ & 300 & Measuring indicators for all major themes. \\
\hline
\end{tabular}

Note: The number of informants reported here is for both regions, thus, half for Northern and Upper East Regions. The breakdown of the survey respondents are as follows: 156 were small-scale farmers, 123 were lower-mediumscale, 14 were upper medium-scale and 9 were large-scale farmers. The latter two groups are relatively underrepresented in our dataset, largely because of tensions between local farmers and their investor counterparts.

Source: Authors' own 


\section{FARM SIZE CHANGES FROM YEARS 2000- 2020 AND THEIR DRIVERS}

Within our quantitative dataset, farm sizes have seen substantial increases within two generations; from about 5 acres $^{2}$ (2.02ha) to the order to 50-100 acres (20.23-40.46ha) between fathers and sons, respectively (see Figure 4.1). We classified farmlands up to 10 acres (4.04ha) as small; 11-50 acres (4.45-20.23ha) as lowermedium; and 51-100 acres (20.64-40.46ha) as uppermedium, and farm sizes beyond 100 acres as largescale. The rise in medium-scale farming is much higher among the lower-medium farmers, who have increased twofold. The small-scale farming category has declined over the period by about a half. Females are also seeing increases in farm sizes, even if their rate of increases is of a lower magnitude compared to their male counterparts (see Figures 4.1). Even though all largescale farmers are male, the percentage of farmers with farmlands categorised as large-scale has been stable in the last 15 years (Figure 4.1).

We now discuss the drivers and dynamics underpinning these farm size changes. The dataset shows that farm mechanisation, agrochemicals, rising consumer demand resulting from population growth and urbanisation, improved infrastructure, and the influence of investor farmers and local rich farmers are the main factors driving the increasing farm sizes witnessed in the study communities.

Overall (from the pooled data), a substantial majority of the farmers attribute farm size increases to the availability of farmlands, increasing demand for food crops, improvement in food crop prices, and increasing availability of mechanisation services. Others also

Figure 4.1: Farm size changes (2000-2020)

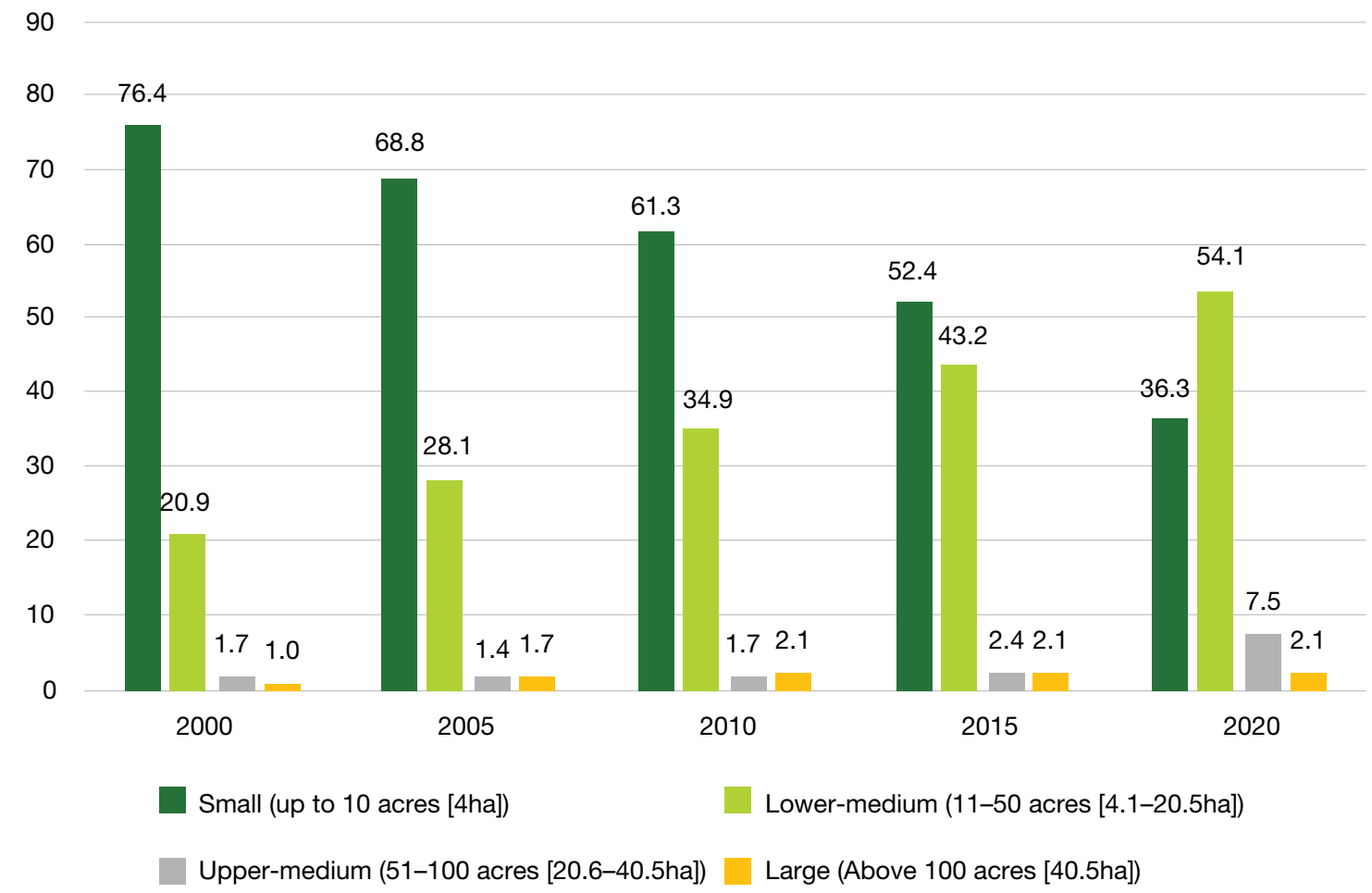

Source: Authors' own (survey data, 2020) 
attribute the rise in the numbers of medium farm sizes to the need to compensate for soil fertility loss, and to meet increasing cost of living. All the largescale farmers surveyed cite availability of farmlands, increasing demand for food crops, and increasing availability of and access to farm inputs as important factors for increasing farm sizes. The upper-medium farmers all indicated that increasing demand for food crops, improved availability of mechanisation tools and agro-chemicals, and increasing costs of living account for the increasing farm sizes being observed. In the rest of this section, we examine the major drivers of farmland increases and agricultural commercialisation in the study area in detail.

\subsection{Mechanisation: The major force for rising farm sizes}

A major driver of the increasing farm sizes in our study communities is the increasing mechanisation of a significant portion of farm activities that farmers hitherto had to manually undertake (see Figure 4.2). With the cutlas and hand hoe as the main farming implements, very little work could be done daily given the high temperature and humidity. The introduction of the animal-drawn plough helped to ease the drudgery associated with farming but even then, farmers could only cultivate a few more hectares, with much of the produce for their own consumption. The real gamechanger has been the introduction of more tractors into the study communities. From the survey data, 10 out of every 11 farmers used tractors in plot preparation, while 10 per cent of the sampled farmers owned tractors. The increased efficiency that modern tractors come with is the major driver for the increasing farm sizes.
A large-scale farmer who has owned and sold four of his old tractors, but currently operates just one, attributes his ability of cultivate the large acreage to tractor use: "Tractors are useful in the expansion because a tractor can do what many farm workers would use several days to accomplish. Current tractors can plough between 15 and 20 acres [6.1 to 8.1ha] a day, depending on the groundworks that are needed" (large-scale farmer, Nyong, August 2020). Similarly, a female farmer explains how the shift from the manual methods of the hand hoe to tractors for land preparation is contributing to the changes in farm sizes: "The tractors and agrochemicals have helped us a lot as they have helped to increase acreage. There are also technologies that help us to harvest and process the farm produce. This encourages us to expand" (female upper-medium farmer, Gbedembilisi, August 2020). Thus, apart from the use of the tractor, other mechanisation tools, such as combine harvesters and rice processors, are also encouraging the increases in farm sizes. With regards to rice, the availability of harvesters is crucial because the crop needs to be harvested at a certain moisture content, and when other factors such as flooding of rice fields impede the ability of the farmer to harvest in time, post-harvest and processing losses could be significant. The availability and use of harvesters at the appropriate time is thus crucial to farmers' motivation to increase their acreages. The affordability of farm machine rentals, and their gradually increasing availability as many upper-medium-scale farmers buy used machines, is encouraging for modernising agriculture in the area. Farm machineries are made available mainly by migrant/urban farmers, rich indigene farmers, and itinerant tractor operators. These groups are assisted by state policies of no or low taxation on

\section{Figure 4.2: A sample of the main farm mechanisation equipment}
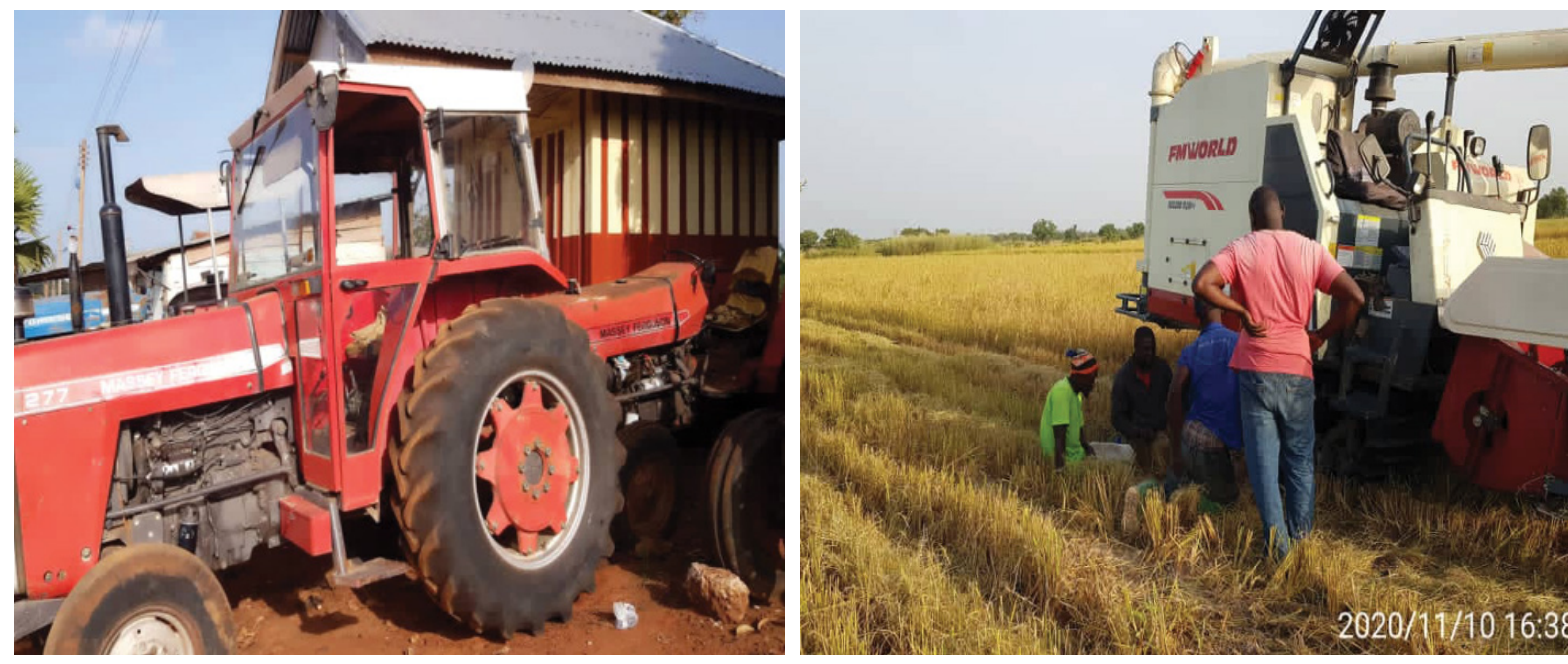

Note: The first frame (left) is a tractor in Nyong, and the second (right) is a combine rice harvester with a crawler in Yagaba near the Fumbisi Valleys, in northern Ghana.

Photo credit: Reproduced with permission of Charles Nyaaba/Peasant Farmers Association 
agricultural equipment and subsidy programmes on equipment. Past efforts at establishing mechanisation centres failed, and the current individual farmer ownership system seems to be an effective pathway for making these services available to all categories of farmers. According to Amanor (2019), within the era of a liberalised markets programme, non-market interventions continue to exist, initiated by the state, development partners, and non-governmental organisations (NGOs). Such interventions encourage uptake of modern technologies by farmers generally, which accounts for the widespread utilisation of mechanisation and other modern agricultural practices.

\subsection{Herbicides and weedicides as facilitators of farmland extensification}

Closely related to the role of mechanisation tools is the critical expansionist role of weedicides and herbicides, and, to a limited extent, fertilisers and improved seeds. Herbicides and weedicides are very effective laboursaving technologies, greatly appreciated by all farmers, though with some environmental consequences. Land clearance is now simply done by spraying the farm with herbicides and cutting a few shrubs, while weeding is replaced by weedicide application with the growing adoption of mono-cropping systems. Except the traditional crops of beans, millet, potatoes, sorghum and yams, all major commercial crops have weedicides, which encourages farmers to increase their farms.

Our survey data shows a significant majority - 89 per cent, 92 per cent, 100 per cent and 100 per cent - of small-, lower-medium-, upper-medium- and large-scale farmers, respectively, see the increasing availability of and access to agro-chemicals as drivers of commercialisation and increasing farm size. This has been supported by macro drivers, such as the government's flagship agricultural programme, named the Planting for Food and Jobs programme, involving seed and fertiliser subsidies.

Like the use of tractors, the use of herbicides and weedicides has considerably reduced the toil associated with farming and unshackled farmers to cultivate larger areas. As an upper-medium-farmer explains: "...because of the chemicals [herbicides and weedicides], is there anyone who bends down to farm again? Their use has helped farmers to expand. You pump the bare land and plant and when the seeds germinate, you pump again, and you will never see the grass again till you harvest. If not so, could we have cultivated many acres? So, the chemicals help us" (elderly farmer, Nyong, August 2020).
A tractor operator also captures the important role that herbicides play in increasing farm sizes by explaining that:

"They have introduced chemicals that even if you cultivated 50 acres [20.2ha], the chemical would clear the weeds by itself. You will not bend down to clear the weeds. No matter the number of acres I plough, as long as the farmer can get chemicals to pump it, he will increase the farm more and plant, and then buy chemicals to pump it to control the weeds. It is the chemicals that will take care of the farm and plants will germinate" (tractor operator, Nyong, August 2020).

The use of weedicides is so widespread that more than nine out of every ten surveyed farmers used it for weed control. This has been possible partially due to the availability of equipment for spraying using manpower, as three out of every four surveyed farmers owned a knapsack sprayer.

An added advantage of the use of weedicides is that they are cheaper and more readily available compared to hired labour for weed control, with the latter often being in limited supply at crucial stages of the farming season. For instance, a farmer needs five units of labour to weed 0.4 ha costing $\mathrm{GHC} 100,{ }^{3}$ while a litre of weedicide costs $\mathrm{GHC} 30$ plus the spraying cost of GHC25, equating to a saving of half the cost of the manual system. Thus, unlike decades ago when only a few farmers dared cultivate more than 4ha bearing in mind the drudgery this entailed, now where cultivable lands are still available, anybody who is minded to increasing their scale of cultivation can conveniently do so with the right resources, given the wide availability of herbicides and weedicides. This is particularly true as the old traditional method of pooling labour to work on individuals' farms is disappearing. For instance, a large-scale rice farmer who started with 10.9ha and then increased 19ha and now cultivates 101.2ha attributes this achievement chiefly to herbicide/ weedicide usage, pointing out that he could not rely on hired labour for such a large farm. Besides, manual weed control on such large farms is impractical. Thus, just like the use of tractors, weedicide use has also removed the excessive labour from farming. A medium-scale farmer captures this succinctly when he posits that: "But for the agrochemicals, you wouldn't have met any of us here. By now we would be on our farms. But the agrochemicals are giving us free time to relax within the farming season" (medium-scale male farmer, Gbedembilisi, August 2020). 
One of the main yield-limiting factors in the production of rice is weed management, as weeds grow very fast and compete with crops for available nutrients. Farmers, therefore, find weedicides a major leap in weed control, with the popular weedicide used in the area under the trade name Bison. Our findings are similar to those of Rodenburg et al. (2019) which show that there is increasing reliance on weedicides to control weeds, with as much as 55 per cent of rice farmers using chemicals to control weeds on their farms. This proportion increases to 82 per cent in field areas between 5 and 10ha and 81 per cent for fields with areas above 10ha in northern Ghana (Houssou et al., 2018).

\subsection{Urban-based investor farmers and local rich farmers as catalysts for agricultural commercialisation}

The activities of investor/urban farmers are another important driver of the general farm size increases and commercialisation in the study communities. The two study districts have historically been attractive to large-scale investor farmers; this is particularly true for the Fumbisi and Weisi valleys in the Builsa District and the rice valleys in the Karaga District, with relative land abundance and fertile local soils serving as the main attractions (Konings, 1984; Kasanga, 1995; Smalley, 2013). The presence and activities of urban-based investor farmers in the various communities encourage farm size increases in a number of ways. First, the investor farmers themselves are noted to cultivate large farms, as farming is their primary reason for coming to such communities and they often have more resources. Even when they start small, they have the social and economic capital to marshal resources to increase their scale of production when needed. This is attested to by a medium-scale farmer who started with 14.2ha but has been farming 38.4ha for the past four seasons as a result of the high profitability: "Farming is a good business. The income I get from farming is far more than what I earn as a teacher. I can pay myself from my farm income about four times what I receive from the state as a teacher" (Investor farmer, Fumbisi, August 2020). Second, their presence makes tractors more readily available to the entire farming population, as some investor farmers own tractors, while their mere presence also creates markets for tractor operators, and so the latter are attracted to communities which host investor farmers. Third, investor farmers often employ local folks who then earn much-needed offfarm income to invest on their own farms. Fourth, they serve as model farmers from whom local farmers learn modern farming methods, such as the use of weedicides and herbicides as well as commercial rice farming. Finally, investor farmers often serve as sources of inspiration for how modern farming on a large-scale could be financially rewarding. A local farmer explains that: "Investor farmers serve as an eye opener and role models to us as we copy their farm practices. They have also introduced us to commercial rice farming" (male medium-scale farmer, Weisi, August 2020). An investor farmer also explains that while he ploughs for the local farmers using his tractor and provides other services, such as serving as a foundation seed grower which contributes to general improvements in farming in the community, his most important contribution, he believes, is becoming a source of inspiration to young farmers in the community. He avers that: "When the young ones see me in my 4-wheel drive Pajero, they are motivated to take up farming as a full-time job and cultivate larger areas" (large-scale farmer, Nyong, August 2020). Our findings are similar to those of earlier studies, such as Lay et al. (2018) and Burke, Jayne and Sitko (2020), which found that, in Zambia, smallholders located closer to medium- and large-scale farmers tend to increase their farm sizes, yields, and levels of commercialisation. The story is similar in Nigeria, where Liverpool-Tasie et al. (2020) found strong evidence of positive welfare impacts for small-scale farmers who engaged with medium-scale farmers in their communities. Apart from the direct impacts, the activities of politically and economically powerful groups, such as large rice farmers, often lead to wider community level developments such as the construction and upgrading of roads, improvements in the supply of electricity, and improved availability of inputs, while also serving as new market actors.

\subsection{Markets: Increasing population and urbanisation creates demand for more food}

Another key driver of increasing farm sizes in the study area is growth in the demand for farm produce, which is underpinned by population growth and urbanisation. Increasing demand for local food is also a reflection of the rising cost of imported foods, which allows for their substitution by local foods as economically sensible. Population growth and increasing incomes and costs of living have ensured that there is consistently increasing demand for food stuffs. This implies that farmers have access to buyers from bigger markets, and so are motivated to increase their scale of production in order to meet the increased demand. As a farmer explains: "Previously, we could keep farm produce until they become stale and then give them away to someone who had exhausted their own free of charge. So, there was no motivation to increase farming beyond subsistence level. Now markets are favourable, and 
we can easily sell any extra produce for cash so there is good reason to increase production" (Elderly lowermedium scale farmer, Nyong, August 2020).

Improved local demand is augmented by improved external demand, driven mainly by improved communication infrastructure - telecommunications as well as transportation - linking study communities to external markets. The deep mobile penetration in the study communities is exemplified by our finding that nine out of every ten surveyed farmers owned a mobile phone. This has helped local farmers to integrate into the global capitalist economy, even if on the fringes. Farmers are able to reach buyers from bigger markets through mobile phones and to compare prices for farm produce in order to make informed choices. From the survey data, as many as three out of every four farmers sold their farm produce in either local or urban markets. Improved connection to urban systems encourages larger farms in two ways. First, there is increased migration to urban centres, and incomes earned from seasonal migration are remitted back to the rural communities to be invested in bigger farms. Second, the improved connection to urban markets has motivated the cultivation of certain crops such as cow pea and rice in the Builsa South District and peanuts and soybeans in the Karaga District on large scales. The improvement in road infrastructure has enabled the availability of bigger trucks, which facilitate trade across Ghana and also with neighbouring countries. The area is realising its potential as the breadbasket of Ghana, as the regional urban markets register hundreds of trucks carting out and bringing in manufactured goods. The emerging food chains, though not well-developed formally, have proven effective in pushing the decision to expand farms and adopt modern technologies. 


\section{SYNERGY: THE RELATIONS AMONG DIFFERENTIATED FARMERS}

This section examines how the different categories of farmers relate to each other in terms of benefit streams and challenges posed to each other. The relationship is largely symbiotic, with important areas of mutual help being labour exchange, technology transfer, farm skills and knowledge transfer, as well as finance and market access. Despite these areas of reciprocity, there are areas of negative spill-over effects which include emerging conflicts, land scarcity, labour scarcities, capture of state support and financial resources, leading to the creation of losers and winners in the processes increasing farm sizes.

\subsection{Labour-capital exchanges between the farmers}

There are significant labour exchanges between the various categories of farmers, with the bulk of this exchange flowing from small-scale farmers to their larger-scale counterparts. The contribution of labour by smaller farmers on large farms provides an important source of financial capital for investing on the formers' farms. Therefore, Table 5.1 presents the source(s) of farm labour across the various farm scales. By looking at how farmers source their labour, we provide insights on the existence of labour exchanges (if any) and labour dynamics for the different categories of farms. We identified three main sources of farm labour - i.e., other household members, members from a reciprocal/ revolving group, ${ }^{4}$ and working for other farmers ${ }^{5}$ in exchange for the use of their machinery. ${ }^{6}$ It is worth noting that these sources of labour are not mutually exclusive, and that farmers typically use a combination of these sources in the production process. Again, while we acknowledge that farm labour contributions by other household members may be seen as part of one's responsibility within a household, its inclusion here is to show any variation across the different farm scales. However, our discussion on labour exchanges focuses more on the other sources, which obviously reflects farm labour beyond household members. Therefore, in Table 5.1, for each source ${ }^{7}$ of labour and scale of farm operation (columns 2-5), we present the percentage distribution of labour exchange. ${ }^{8}$ From Table 5.1, at least half of the farmers (except upper-medium-scale)

Table 5.1: Labour exchanges between and amongst scales of operation (in percentages)

\begin{tabular}{|l|l|l|l|l|}
\hline \multicolumn{5}{|l|}{ By scale of operation } \\
\hline Labour use & \multicolumn{5}{|l|}{ Small } & Lower-medium & Upper-medium & Large \\
\hline Contribution from household members & 96.2 & 95.1 & 85.7 & 100.0 \\
\hline Yes & 3.9 & 4.1 & 14.3 & 0.0 \\
\hline No & \multicolumn{5}{|l|}{} \\
\hline Use of reciprocal/revolving labour & 51.3 & 59.8 & 42.9 & 57.1 \\
\hline Yes & 48.7 & 40.2 & 57.1 & 42.9 \\
\hline No & 75.6 & 79.5 & 78.6 & 100.0 \\
\hline Labour-for-capital & 21.8 & 18.9 & 21.4 & - \\
\hline Yes & 2.6 & 1.6 & - & - \\
\hline No & & & \\
\hline Not sure & &
\end{tabular}

Source: Authors' own (survey data, 2020)

$4 \quad$ Conditional on being a member of that group

5 Typically, medium and/or large-scale operator

$6 \quad$ Mostly tractors

$7 \quad$ Indicated by rows

8 This means that each labour source under each farm scale should add up to 100 per cent 
are engaged in this labour exchange. Although not necessarily direct beneficiaries, the majority (at least 75 per cent) of respondents noted the exchange of labour for capital which goes on between small and bigger farmers (row for labour-for-capital). Although revolving labour - a system whereby farmers provide labour on each other's farms on a rotational basis - is waning in popularity, it is still an important means of labour exchange, reported by 51 per cent, 60 per cent, 43 per cent and 57 per cent of small, lower-medium, uppermedium, and large farmers, respectively.

Different groups - older children, ${ }^{9}$ women, and men - perform various activities - planting, fertiliser application, and uprooting of shrubs and trees on fallowed or virgin lands - for large farmers for cash payment. Other times, payment for such services could be in-kind through bigger farmers ploughing for their smaller counterparts. Other services by bigger farmers to small farmers include clearing of farmlands, helping cart farm produce from their farms to their houses using tractors, and providing transportation for smaller farmers to and from their farms. While these services may not be direct labour contributions, smaller farmers consider these as benefits they derive from the presence of bigger farmers in their respective communities.

The main contribution of bigger farmers to their smaller counterparts relates to the use of their farm machinery on the latter's fields. In addition to ploughing using their tractors, bigger farmers also shell the cowpea, groundnuts, maize, and soybean of smaller farmers and harvest their rice using tractors and combine harvesters. These services are often paid for with farm produce - the general rate being a bag of whatever crop is produced by the smaller farmer per hectare. Such payments are useful for fuelling the tractors in order to plough their own farms. Smaller farmers perceive that bigger farmer who hail from the same communities are of greater help than their counterparts who are not indigenes. This is in line with the findings of Chamberlin and Jayne (2020) that the benefits that accrue to the small farmers are maximised if the two categories of farmers share common social, ethnic or familial connections. This is collaborated by a large-scale farmer (although not originally from Nyong, has lived in the community for more than 20 years and is thus considered a member of the community) who often ploughs about 0.811.2ha extra for small farmers free of charge.
There is some collaboration between bigger farmers, particularly in what we term 'labour relays' whereby large-scale farmers import labourers into a community and refers them to another large farmer after they are done with work on the former's fields. As a farmer narrates during a FGD: "Sometimes what we do is that if I get the number of labourers I need and my colleague farmer does not, I will refer the labourers to him immediately after they finish working on my farm. If they finish on his farm and are still willing to work again, then he will also refer them to another farmer. But we also have people in this community who work as farm labourers" - (male farmer, FGD, Nyong, August 2020). Other forms of collaboration relate to the performance of supervisory roles by medium-scale farmers who are resident in the communities for larger investor farmers. Payment for such services often comes in the form of ploughing for the medium-scale farmer.

Upper-medium and large farmers create a vibrant production zone, which makes use of both local and extra-local labour thereby providing employment and a source of capital for reinvesting in the local economy. The attraction of labour to the community also benefits the small farmers, who also hire a significant portion of their labour from this group. Similarly, as labour is brought in by larger farmers it frees up the local labour for use by lower-medium farmers, although we had some community members complaining and resisting 'stranger labourers' because they claim they are taking their jobs and deflating wage rate. van Hear (1984) argues that there is little evidence that casual wage workers were engaged in the north on any substantial scale prior to the development of largescale rice farming, which buttresses our point about the role of investor farmers cultivating large acreages in propelling a labour revolution in northern Ghana. The rice experiments from the 1970s stand as the most significant moments in the commercialisation of agriculture in northern Ghana, even if they were associated with mostly urban-based investor farmers. The development of new road infrastructure and relations between investor farmers and indigenous local farmers has spurred a local endogenous revolution over the years, with changing government policies towards modernising smallholder farmers.

\subsection{Technology transfer}

There are several sources (formally or informally) from which farmers can gain or learn new technology to farm efficiently and increase productivity. These may

$9 \quad$ While one might argue that work by under 18-year-olds constitutes child labour, here we refer to older children between 15-18 years of age who join their parents or carry out less strenuous farm work on other farmers' fields for some cash income - sowing and broadcasting seeds being the most popular. 
include inter alia from other farmers, ${ }^{10}$ agriculture extension officers, NGOs, and the media. Therefore, the survey inquired from farmers the source(s) of new technology learned, and this is represented in Table 5.2. We categorise information on farmers' source(s) of new technology into three categories: small-scale farmers; medium- and large-scale farmers; and other source. The latter is made up of NGOs, farmer groups, extension officers or mass media. Again, given that the different stage of the production process may require different technology, we carry out the discussion in terms of scale of operation and the source of the technology learned.

First, and quite surprising, it appears small-scale farmers rarely learn new innovations or technology from medium/large-scale farmers. Rather, they learn new technology through media/NGO/extension officers/ farmer groups or from their colleague small-scale farmers. For instance, among small-scale farmers who use improved seeds, nearly half of them (48.4 per cent) learned through the media/NGO/extension officer/farmer groups. Then, about 44 per cent of them learned from other small-scale farmers. For most of the new technology learned, on average, only about one in every ten small-scale farmers learned from medium/ large-scale farmers. However, medium/large-scale farmers are relatively more instrumental with regards to processing farm output, as about 23 per cent of smallscale farmers learn from them (Table 5.2).

Although more of the lower-medium-scale farmers (relative to their small-scale counterparts) gain new technology from medium/large-scale farmers, the majority of lower-medium farmers also rely on other sources, particularly for improved seeds (45.4 per cent), planting techniques (42.9 per cent) and fertiliser application (38.3 per cent). Not surprisingly, among upper-medium and large-scale farmers, their main source of new technology is either their counterparts within the same scale or the other source category. Nonetheless, there is some form of bottom-up transfer of technology, in that about one in ten of medium/largescale farmers learn some new technology from smallscale farmers. The data also shows the importance of state efforts and that of NGOs in spurring the new agricultural transformation, as all categories of farmers rely on extension services, state subsidies, NGOsupported programmes, and techniques propagated by the media and sponsored by the state or NGOs.

From the qualitative data, there is considerable knowledge sharing, both active and passive, among the various categories of farmers. From the perspective of larger farmers, especially the non-indigenes, local small farmers not only show them areas with fertile

Table 5.2: Source of technology transfer among different scales of operation (in percentages)

\begin{tabular}{|c|c|c|c|c|c|c|}
\hline Source & $\begin{array}{l}\text { Improved } \\
\text { seeds }\end{array}$ & $\begin{array}{l}\text { New planting } \\
\text { technique }\end{array}$ & $\begin{array}{l}\text { Fertiliser } \\
\text { application }\end{array}$ & Herbicides & Tractors & $\begin{array}{l}\text { Machines for } \\
\text { processing }\end{array}$ \\
\hline & \multicolumn{6}{|l|}{ Small scale } \\
\hline Small & 43.9 & 44.2 & 44.4 & 44.2 & 48.4 & 39.3 \\
\hline Medium/large & 7.7 & 10.9 & 10.5 & 9.6 & 15.5 & 23.3 \\
\hline \multirow[t]{2}{*}{ Other } & 48.4 & 44.9 & 45.1 & 46.2 & 36.1 & 37.3 \\
\hline & \multicolumn{5}{|c|}{ Lower-medium } & \\
\hline Small & 33.6 & 35.3 & 36.7 & 33.6 & 32.8 & 26.9 \\
\hline Medium/large & 21.0 & 21.9 & 25.0 & 27.1 & 36.9 & 37.0 \\
\hline \multirow[t]{2}{*}{ Other } & 45.4 & 42.9 & 38.3 & 27.1 & 30.3 & 36.1 \\
\hline & \multicolumn{5}{|c|}{ Upper-medium } & \\
\hline Small & 14.3 & 21.4 & 21.4 & 14.3 & 21.4 & 14.3 \\
\hline Medium/large & 57.1 & 50.0 & 42.9 & 50.0 & 57.1 & 57.1 \\
\hline \multirow[t]{2}{*}{ Other } & 28.6 & 28.6 & 35.7 & 35.7 & 21.4 & 28.6 \\
\hline & \multicolumn{5}{|l|}{ Large } & \\
\hline Small & 14.3 & 14.3 & - & - & 14.3 & 14.3 \\
\hline Medium/large & 42.9 & 42.9 & 42.9 & 57.1 & 57.1 & 57.1 \\
\hline Other & 42.9 & 42.9 & 57.1 & 42.9 & 28.6 & 28.6 \\
\hline
\end{tabular}

Source: Authors' own (survey data, 2020)

10 Who may be operating as small-, medium- (lower or upper) or large-scale 
lands, but also what crops do best in these areas. In turn, larger farmers disseminate technologies such as new and improved seeds, new agro-chemicals and farm practices, as well as popularising the cultivation of certain vegetables. The latter is particularly true in Weisi and Gbedembilisi. Further, larger farmers, by virtue of their scale of production bring with them tractors, harvesters, and threshers, which are patronised by their small-scale counterparts. Some lower-mediumscale farmers learn how to operate some of the farm machinery from larger farmers. It was also found that farmers who are closer to larger farmers tend to be able to plough larger areas due to easier accessibility to tractors. This is also in line with the findings of Lay et al. (2018) and Burke, Jayne and Sitko (2020) of similar processes in Zambia. The widespread use of tractors among all categories of farmers is mainly due to the support of upper-medium and large farmers who make these available after cultivating their own fields to the lower levels.

It is, however, pertinent to note how certain sociocultural factors could be impeding technology transfer among the different categories of farmers. There is a general belief in some of the communities that one could curse the crops of another farmer out of jealousy. Thus, farmers are careful in visiting other farmers' fields for fear of being accused of having cursed the crops in cases of crop failure. This inhibits learning new farming practices from other farmers. An older female farmer who normally goes elsewhere to search for information refuses to ask her neighbours, for fear of being accused of spiritually destroying their farms. She said: "...because I am an old woman, I can't ask questions about my neighbours farm. In our Dagbon locality, there is the belief that when you ask such questions and subsequently, the crops fail to yield, you will be blamed for it" - (Excerpt from an interview with a 50-year-old female farmer in the Karaga District, August 2020). This reduces the possibility of contagion diffusion mechanisms postulated by Hägerstrand (1968).

The learning processes and innovation diffusion is both vertical and horizontal, but with horizontal spread being higher and preferred because of the common characteristics farmers share. Ecologically defined knowledge is the preserve of smaller local farmers, while mechanisation and westernised innovations are generally diffused by extension services, NGOs, and larger farmers.

\subsection{Farm skills and management}

Modern farming requires that farmers acquire certain skills or management qualities to successfully keep records and apply specific technology (where necessary) throughout the production process. In this regard, Table 5.3 presents farmers' sources of farm skills and management.

Majority of small-, lower-medium and upper-mediumscale farmers (54 per cent, 63 per cent and 86 per cent, respectively) rely on skills acquired from forefathers (traditional). Even among the large-scale farmers, the majority (43 per cent) of them acquired farm skills traditionally. This clearly emphasises the role of tradition and intergenerational transfer of farm skills in Ghana. Only about one in ten small- and upper-medium-scale farmers source farm management skills from extension officers or mass media. This is similar to the findings by Wahab (2020) that the most important source of farming knowledge for farmers is indigenous knowledge from forebears, with only two out of every ten farmers citing extension services. Surprisingly, relatively many lower-medium-scale farmers (21 per cent) than their upper-medium counterparts (14 per cent) acquire farm management skills from agricultural extension officers. Unsurprisingly, more large farmers source their skills in farming from agricultural extension officers than any other farmer category. This is also supported by the qualitative data, as smaller farmers perceive that larger farmer tend to monopolise extension services due to their ability to summon extension officers. On the one hand, small farmers aver that the closer their farms are located to those of larger farmers, the more likely they are to receive extension support. An investor farmer, on the other hand, explains that access to extension services is a general challenge but the proliferation of mobile telephone coverage enables some large

Table 5.3: Farm skills and management relations among farmers (in percentages)

\begin{tabular}{|l|l|l|l|l|}
\hline Labour use & Small & Lower-medium & Upper-medium & Large \\
\hline Inherited traditional & 53.9 & 63.1 & 85.7 & 42.9 \\
\hline Neighbour/relative & 21.2 & 11.5 & - & 28.6 \\
\hline Agricultural extension officer & 13.5 & 20.5 & 14.3 & 28.6 \\
\hline Media & 10.9 & 4.1 & - & - \\
\hline Other & 0.6 & 0.8 & - & - \\
\hline
\end{tabular}

Source: Authors' own (survey data, 2020) 
farmers to be able to reach extension officers and sometimes even send photographs of pest-infested plants for recommendation and advice. This is also because small- and lower-medium-scale farmers tend to use ordinary cell phones, while richer and larger farmers use smart phones with internet capabilities and thus with wider utility.

In terms of exchanges and transfer of such technical skills and management acumen, there is a significant level of interaction between and among the various farmer categories. As a farmer avers during a FGD in the Karaga District: “... a large-scale farmer can learn something new from a small-scale farmer who has more experience, and a small-scale farmer can also learn modern techniques from a large-scale farmer. We all take advice from each other" (50-year-old male farmer, Nyong, August 2020). Thus, small farmers share with big investor farmers their local knowledge about the nature of the soil and its suitability for particular crops, which areas are fertile, and which are water-logged areas and thus unsuitable, as well as other critical farming information such as timing of planting, and useful traditional farm practices. On the other hand, when small farmers are employed on larger farms, they tend to pick up new skills from larger farmers or through experimentation using the resources available. This is particularly true with regards to seed varieties, use of agrochemicals, methods/spacing of planting, as well as harvesting and produce storage. Large investor farmers are noted to perform better in fertiliser and herbicide/weedicide application practices, which have proliferated in the study communities in recent times through the interactions between local farmers and their investor counterparts. For instance, smaller farmers are increasingly moving from the traditional and popular Mandinka rice variety to the Alliance for a Green Revolution in Africa's improved variety, just as they have done with maize in the past. Though they had heard of these new varieties from the extension officials, it is the actual cultivation experiences of larger farmers that provide proof that these new seeds are efficient and yield better, thereby increasing incomes and food. Therefore, larger farmers' introduction of new varieties and farm practices gives confidence to smaller farmers to adopt them. Compared to the findings by Liverpool-Tasie et al. (2020) for Nigeria, where they find knowledge and cost spill-over effects, with small farmers buying inputs from medium-scale farmers and selling their products to them. Conversely, the Ghanaian farmer relies more on the support of the state in the form of extension and traditional local market value chains. The channels and mechanisms through which medium-scale farmers and small-scale farmers interact to improve productivity are qualitatively different in Ghana and Nigeria.
Again, certain sociocultural structures inhibit the sharing of knowledge among farmers. Some traditional structures prevent female farmers from interacting with non-relatives and non-indigene farmers. During a female-only FGD in Nyong, a female farmer explains that one could only learn new skills from a bigger farmer if one is hired to work on the farm: "As a woman, one cannot just go to a stranger to learn something; it is easier if the large farmer is a relative." Women in such sociocultural contexts would be limited to farm skills and knowledge available to their close relatives.

\subsection{Finance and marketing}

There are significant levels of interaction between and among the various categories of farmers in the study communities as far as finance is concerned. On their part, smaller farmers earn wages from working on larger farms. Wage earning-activities on larger farms include broadcasting or sowing of seeds, fertiliser application, and winnowing and bagging of produce. Some small-scale female farmers also collect left-over rice from large investor farmers' rice fields after harvest. Such earnings are helpful in financing their own farm activities. Beyond earning incomes from larger farms to invest on their farms, some smaller farmers also receive non-monetary support from larger and urban-based farmers, such as ploughing on credit to be repaid at harvest, either in kind or cash.

The support that larger farmers offer to smaller ones is often not out of altruism, but rather practical necessity. Below a certain minimum threshold, tractor ownership becomes uneconomical. Farmers put this limit to be able to break even at 80.9ha. That is, larger farmers who have had to reduce their area of cultivation, for one reason or another, need to plough for other farmers in order to maintain the tractor. Such income from rentals helps to purchase fuel for tractors for the owners' own farming activities, as well as defraying some of the maintenance costs. Indeed, some uppermedium-scale farmers report giving financial support to tractor owners who, in turn, plough for them as payment. Sometimes, some of the small farmers are dishonest such that after getting their farm ploughed on credit, claim that the crops have failed. The honest ones will bring the large farmer to the farm to verify the state of the crops and large farmers who are reasonable often write-off such debts. An uppermedium-scale farmer recounts how the indebtedness of small-scale farmers to her sometimes creates further problems in terms of her access to farm labour: "I provide help to smaller farmers to the best of my ability. The challenge is when I need these same individuals as farm hands, they will refuse to show up, fearing that I would use the debt owed as payment for 
labour." We see a complex web of interrelationships between labour, capital, finance, and technology, with trust as an important intermediate variable.

Livestock has, for a long time, been the major source of finance for crop cultivation and a source of savings from crop revenue. Farmers are now more willing to diversify their investments from the livestock subsector, especially the keeping of large ruminants into the cultivation of larger farms. As a farmer explains: "Initially, our father was reluctant to sell cattle to invest in farming, but now we do. The cattle are now being stolen and it is not wise to have them stolen instead of selling and using the money to expand your farming area" (Male farmer, Gbedembilisi, August 2020). This is supported by the quantitative dataset which shows that livestock are a critical income source, contributing 25 per cent of all household income, second only to grain sales at 36 per cent, with 37 per cent of the surveyed farmers ranking livestock sales as the second most important income source. Urbanbased investor farmers often serve as main buyers or aggregators for the increasingly important livestock market. The thefts of livestock have been attributed to a lack of shepherd boys, as children are increasingly enrolled in schools which is a direct consequence of increasing modernisation.

In terms of marketing, the interactions among farmers are minimal. This may be attributable to the fact the different categories of farmers predominantly rely on different avenues to market their farm produce. While a majority of small- and lower-medium-scale farmers rely on local markets in the marketing of their produce, most large farmers use urban markets to sell off their farm produce. As noted previously, different crops perform differently in the various types of markets, and so for small farmers for whom it is uneconomical to transport a few bags of their maize or soyabeans to regional and urban markets, selling to aggregators at the farm gate or from home becomes a more attractive option.

It is also important to note that the presence of large farmers often attracts large produce-buying companies into the communities. Such companies tend to offer relatively better prices, thereby benefitting the smaller farmers, too. This is, however, not to say that the different groups rely on each other to market their farm produce, except for special crops such as soybean and rice. The well-established traditional marketing channels of local periodic markets and urban markets are given a boost when buyers are sure of plentiful supply of farm produce over longer periods, which is guaranteed by medium-scale production. 


\section{CONTRADICTIONS: LOSERS AND WINNERS OF THE PROCESSES OF RISING FARM SIZES}

We now discuss the emerging negative consequences that are associated with rising farm sizes and a commercial agricultural ethos. We examine challenges with land, labour, input availability, and contributions to the local economy, showing contradictions against the claim that medium and large farmers co-exist well with their smaller counterparts. Rather, processes of change in access to productive resources, and the emerging dependencies and exploitative tendencies contradict these assertions of synergy, peaceful co-existence, and harmonious relations. We argue that the political economy of who controls access to resources, and the rights of individuals in society in the context of changing rules and norms, are important in understanding the socio-economic relations between the socially differentiated farmers. Thus, while the trends of increasing farm sizes and commercialisation of agriculture produce synergistic benefits to local development, they are also fraught with negative spillover effects that create losers in the process. Generally, the biggest beneficiaries of these farm size increases are urban-based and investor farmers, the chiefs, and wealthy local farmers, with very few women. The majority of youth and women, though participants of the processes, only benefit marginally.

Traditionally, land is owned by the community, but under the control of traditional leaders in many parts of

Table 6.1: Difficulty/ease of access to and/or use of farmlands (in percentages)

\begin{tabular}{|c|c|c|c|c|c|}
\hline & \multicolumn{5}{|c|}{ Scale of operation } \\
\hline & Pooled sample & Small-scale & $\begin{array}{l}\text { Lower-medium- } \\
\text { scale }\end{array}$ & $\begin{array}{l}\text { Upper-medium- } \\
\text { scale }\end{array}$ & Large-scale \\
\hline \multicolumn{6}{|l|}{ Availability } \\
\hline Improved & 37.8 & 26.9 & 47.5 & 50.0 & 85.7 \\
\hline Unchanged & 47.8 & 58.3 & 38.5 & 28.6 & 14.3 \\
\hline Worsened & 14.4 & 14.7 & 13.9 & 21.4 & - \\
\hline \multicolumn{6}{|l|}{ Affordability } \\
\hline Improved & 31.4 & 24.4 & 37.7 & 35.7 & 71.4 \\
\hline Unchanged & 47.8 & 53.2 & 42.6 & 42.9 & 28.6 \\
\hline Worsened & 20.7 & 22.4 & 19.7 & 21.4 & - \\
\hline \multicolumn{6}{|l|}{ Conflict } \\
\hline Improved & 55.5 & 48.1 & 63.9 & 57.1 & 71.4 \\
\hline Unchanged & 28.8 & 36.5 & 21.3 & 14.3 & 14.3 \\
\hline Worsened & 15.7 & 15.4 & 14.8 & 28.6 & 14.3 \\
\hline \multicolumn{6}{|l|}{ Unclear rules } \\
\hline Improved & 47.2 & 39.1 & 54.9 & 57.1 & 71.4 \\
\hline Unchanged & 41.1 & 47.4 & 35.3 & 28.6 & 28.6 \\
\hline Worsened & 11.7 & 13.5 & 9.8 & 14.3 & - \\
\hline \multicolumn{6}{|c|}{ Tenure reduction } \\
\hline Improved & 41.8 & 38.5 & 45.9 & 35.7 & 57.1 \\
\hline Unchanged & 46.2 & 48.7 & 44.3 & 42.9 & 28.6 \\
\hline Worsened & 12.0 & 12.8 & 9.8 & 21.4 & 14.3 \\
\hline
\end{tabular}

Source: Authors' own (survey data, 2020) 
the country; and so, there cannot be an outright sale of lands. Therefore, lands are leased out for a negotiated and agreed period of time. As expected, the rise in medium-scale farms has increased the demand for land which has generated new terms and conditions, and interests in the control of land. These emerging dynamics degenerate into conflicts among the different actors, and induce changes in social relations which depended on land relations. The changes to land relations are aptly captured in Table 6.1, which presents the difficulty/ease with regard to access to and/or use of land in the study area by looking at the pooled sample, and from the perspectives of scale of operation. While the biggest improvement in land-related issues is seen in the area of conflicts with about 56 per cent of farmers indicating this (see column 2) - the biggest challenge now is affordability, as about one in every five farmers cites the issue of land affordability as having worsened. Rules governing access to and/or use of land have improved (according to 47.2 per cent of farmers interviewed).

Generally, there are no overt conflicts in the study communities. This notwithstanding, the qualitative data shows that areas of emerging conflict include exhaustion of fertile lands, competition for developed rice valleys, and boundary disputes between farmers. Small- and medium-scale farmers who foresee an opportunity to increase their scale of operation are beginning to be apprehensive about the presence and activities of large urban-based farmers, as the latter are contributing to farmland scarcity.

Some indigenous medium-scale farmers report that there are no more virgin lands, so if one needs to further expand farm area, they often have to beg from community members who may not be using all of their farmlands. There is, thus, a feeling of jealousy between investor farmers, who tend to be more successful, and the local folks, who feel their birth-right - farmlands are being expropriated from them. This competition for farmlands is most keen in the developed rice valleys with developed government bonds. While there are large portions of the valleys that are yet to be developed, there is strong competition for the developed sections that have been partitioned into bonds. Due to these tensions between native farmers and their investor counterparts, a large section of the Gbedembilisi rice valleys were left uncultivated in the 2020 farming season, which accounts for a lower representation of urban-based large farmers in our sample.

Another area of increasing conflict is boundary disputes. These occur most in communities in which farm sizes are seeing greater expansion. Boundary disputes often occur between farmers who have the wherewithal to increase their area, and those who do not. Such relatively wealthier farmers tend to plough into neighbours' allocations. Generally, people are agreeable such that after the current season, boundaries revert back to their original limits. Land and boundary disputes between community members are thus usually easily resolved by community elders, but if that were not possible, it is then escalated to either the Earth Priest, the chief, or both to resolve. This collaboration becomes difficult when there is friction between the Earth Priest and the chief, which occurs due to disagreements over who actually controls and thus can give farmlands away to investor farmers. As the Earth Priest in one of the communities in the Builsa South District avers: "I have a disagreement with the chief over who controls the land in this community. The reason being that I am in charge of the land and the chief's domain is the people, so the chief must allow me to exercise that control over the land" (excerpt from an interview with an Earth Priest, Builsa South, August 2020).

The chiefs who allocate lands, especially to large-scale investor farmers, are now in very good economic and political standing. The emerging contestation between chiefs and Earth Priests for allocation rights to land, in order to earn rent, creates social instability in traditional governance circles. Traditionally, the farmlands are not rented to these investor farmers, but they are expected to pay a token at the point where they are given access. They are also expected to show appreciation to the Earth Priest and/or the chief after every harvest. Apart from the Karaga District, where this traditional access route to farmland is still intact, that of the Builsa District and the adjoining Mamprusi communities were actively receiving prescribed rent of one bag of rice per acre (0.4ha) from urban-based investor farmers. These landed rents exacted are enriching the royalty, together with the council of elders, amidst agitations and violence from the youth who occasionally disrupt farming activities of investors. Even in Karaga where rents are silent, taking the form of cash and gifted bags of crops before and after harvest sent to the royalty and their league of sub-chiefs, this system enriches those in power. Therefore, those in power are happy to interpret land tenure rules and norms in their own favour. Some investor farmers also report using their tractors to plough the fields of the chiefs of the communities, which they operate free of charge. This leads to increasing scarcities of land, because most of the highly productive and accessible lands are occupied by rich indigenes and urban-based investor farmers. Though land was observed to be abundant in the Builsa area, poorer households without the wheels to travel far from the community and the technology to bring such bushy areas to cultivation can only expand their farmlands marginally. The frontiers of production expansion seem to be almost reached in the Karaga District. 
The changes in labour relations have tended to produce their own set of contradictions, though, linked to land. The labourers in these communities are among the poorest, as they earn meagre wages and are deprived of the time and energy necessary to cultivate their own farms. Therefore, small farmers are the worst off, followed by lower-medium-scale farmers. There is, thus, a semi-proletarianization process taking place, whereby poor households are trapped in subsistence, small-scale production while providing labour services for medium- and largescale farmers. The semi-proletariat are entrapped in relations of dependence and exploitation, as they rely on bigger farmers for ploughing services, capital from labour-capital exchanges, and repayments at higher rates. Poorer farmers will have to provide services to richer ones before returning to their farms, which may then not produce such high yields due to suboptimal timing. For instance, late weeding, when weeds have already degraded fertility through competition for soil nutrients, leads to their strangulation; and late harvest of rice and soybean can lead to destruction by bushfires or losses through dropping on the ground or crops being eaten by birds and other animals. Though a blessing to be employed casually, it is an unreliable livelihood and cannot be sustainable. Seasonal employment may provide palliative wages to meet minute investment expenditures, which keeps poorer farmers from drowning in extreme poverty, but this is simply hanging in. In terms of losers in the process of farmland expansion, we identify farmers engaged in the provision of labour as a dependency to bigger farmers, such as small poor farmers and women farmers, as major losers.

In terms of changes to social organisation of the communities and farmers, we find a new structure where upper-medium- and large-scale farmers are contrasted with the small and lower-medium farmers. This social differentiation leads to each actor seeking better terms for their group. Generally, large commercial farmers tend to be better organised and closer to state authorities and are, therefore, able to channel their grievances and challenges for redress. This reflects the ideas of the political settlement theory, which argues that actors often defend their own interests and seek more allocation of resources for themselves against other actors (Teye and Nikoi, 2021). Though the actions of the politically and economically powerful groups, such as large rice farmers, often lead to wider community level benefits, such as construction and upgrading of roads, supply of electricity, availability of inputs and new market actors, the dynamics of these tend to disproportionately benefit the bigger farmers over their smaller counterparts. The mechanisms are the same as when a subsidy is introduced; the benefits accrue more to large farmers because they buy more of the inputs than smaller farmers. Another typical example is the mechanisation drive by the state and even NGOs, which provides rich farmers access to more subsidised tractors and equipment (Amanor, 2019). Even cheaper NGO-sponsored locally fabricated equipment, such as corn shellers and groundnut threshers, are more accessible to upper-medium-scale farmers than small-scale farmers. Both economic and political power defines access to resources, which creates winners and losers in the ability to scale up farm sizes in the right locations, adopt technologies, and access lucrative markets and buyers. For instance, larger farmers of rice and soyabeans often use the media to complain about surpluses at the farmgate, then negotiate good deals with attracted buyers, while smaller farmers who may benefit from this move receive lower prices due to their inability to meet specifications of buyers, or because an aggregator/middleman buys from them on behalf of the main company.

An important group of winners in the processes of transformation in agriculture includes the owners of machinery and agro-input shops whose businesses receive great boosts from the expansion of farmlands, just as they are drivers of rising farm sizes. Machinery owners earn considerable rental fees and in-kind crop produce from those who cannot afford to pay in cash. The profits of agro-input shops are increasing because of the widespread adoption of herbicides, weedicides, pesticides, fertilisers, and seeds. Medium-scale farmers are important for the survival of these actors because of their sheer numbers compared to large farmers, who may procure their own inputs and own machinery from major suppliers. Though beneficial to all categories of farmers, it leads to a dependency on these actors for the survival of their farms, thereby making them vulnerable. Small farmers report making concessions to larger ones with machinery to their detriment because of dependency. The dependency on the local agro-input dealers has led to serious problems involving poor seeds, fake chemicals, and higher prices without any possibility for farmers to claim compensation or seek redress due to poor governance of the sector.

Agricultural policies in Ghana, which have been aimed at modernising the sector to meet food security and ween Ghana from excessive dependence on food imports, have made subsidised inputs available to farmers. Although all farmers theoretically have access to these inputs through the agricultural extension services, larger farmers tend to gain more than smaller ones. The agricultural subsidy programmes run by the state under different names over the years have suffered the same fate, with the capture and smuggling 
of especially fertilisers to neighbouring countries a major problem. Politically connected suppliers and large farmers are guilty of these practices. Also, on the grounds of expediency, extension services may also prioritise upper-medium-scale farmers claimed to have the potential for output growth to the detriment of female and small-scale farmers. Similarly, some interviewees complain of extension services being more available to bigger farmers than smaller ones. This is indicative of the natural tendency to align with more powerful groups for reciprocal benefits than with weaker social groups. Greater access to subsidised inputs and extension services therefore reinforces existing inequalities, as wealth accumulation of the powerful winners occurs to the disadvantage of weaker groups. Competition for farm inputs, particularly fertilisers, is an important area of emerging conflicts. Fertiliser distribution channels to communities are either through private dealers or government channels. The latter is usually cheaper due to government subsidies. Conflicts emerge when a large farmer purchases almost half of the whole government-subsidised fertiliser allocation for an entire community, though not allowed by the rules of the state. To deal with this challenge, farmers for each community are made to register with their identity cards during the off-season before the distribution starts. Distributors for the state-subsidised fertiliser have also placed a ceiling on the quantity that each registered farmer can buy. These measures have enabled some recent productivity gains by smaller farmers whose allocations of ten bags of fertiliser match very well with their farm size, leading to higher productivity and even higher use of fertiliser than bigger farmers per hectare.

Increasingly, women, especially the poorer ones, and the latecomers into commercial farming are at the losing end. The shifting production frontiers are moving far from the settlements, which necessitates the ownership of motorbikes and tricycles to access new farmlands. Poorer households and the majority of women who cannot afford the modernised motorised equipment face land scarcities in an otherwise generally land-abundant community. It is, therefore, only those with the capital accumulated from previous farming of relatively bigger plots who can increase farmlands in the moving production frontier. A cluster of disadvantages similar to that described by Chambers (2014) continues to keep these groups from social upward mobility. In addition, existing paternalistic norms about land ownership, spousal responsibilities, and forms of appropriate associations between men and women leads to disadvantages for women that prevent their participation in the higher levels of expansion. Their dependence on males for access rights to land, the exploitation of their labour by household heads and their husbands, and their position as the last to benefit from government assistance, makes women the losers in the 'golden era of agrarian change'.

The development of the local economy in the districts would have been higher if majority of the bigger farmers were indigenes residing and working in those areas. The stepping-in by investor farmers supersedes the stepping-up of local farmers who have the resources to increase their scale of production. This is important because the benefits that accrue from increasing commercialisation of farming tends to be maximised when majority of the larger farmers have stepped up rather than stepped in. This is because the former tends to spend most of their increased incomes within the rural economy compared to the latter (Johnston and Mellor, 1961; Mellor, 1976; Chamberlin and Jayne, 2020). Hopefully, the increasing stepping-up witnessed from small- to lower-medium-scale will further move to the next levels in the next decade, thereby giving us a majority situation. However, if investments by these local farmers are not made within their community, this theory will be of no use. Already, most farmers in Karaga District are investing in the urban communities of Savelugu and Tamale where the returns to housing and other businesses are higher, to the disadvantage of their local economies. Therefore, new spatial winners in the process of agricultural commercialisation involving increasing farm sizes are the nearby cities, which siphon off capital accrued from farming. Spatially, bigger communities with local markets tend to benefit more than smaller ones without markets and the necessary population to spawn a non-farm sector.

Table 6.2: Standard of living of different farm scales and gender (based on respondents' own assessment) (in percentages)

\begin{tabular}{|l|l|l|l|l|l|l|}
\hline & \multicolumn{3}{|c|}{ Scale of operation } & \multicolumn{3}{c|}{ Gender } \\
\hline Standard of living & Small & Lower-medium & Upper-medium & Large & Female & Male \\
\hline Poor & 33.3 & 15.6 & - & - & 31.6 & 20.9 \\
\hline Average & 58.3 & 56.6 & 42.9 & 28.6 & 58.2 & 55.5 \\
\hline Rich & 8.3 & 27.9 & 57.1 & 71.4 & 10.1 & 23.6 \\
\hline
\end{tabular}

Source: Authors' own (survey data, 2020) 
The implications of the rising trends in farm sizes, as reflected in improvements in standards of living of different social groups and gender, show a landscape of winners and losers. From Table 6.2, the small and lowermedium farmers have lower standards of living than the upper-medium and large farmers, which reflects higher income resulting from greater output from larger farms, more use of technology and better markets.

Poverty was more prevalent among women than men; as almost one in every three female farmers was poor compared to about one in every five male farmers, which shows how the various constraints faced by women in joining the commercialisation regime have implications for their income and wellbeing. The majority of large-scale farmers (57 per cent) were within the richest group.

In terms of food and nutritional security, we find that although a good number of small-scale farmers experienced improvements in their diets, that group is still a vulnerable one that needs upscaling of farms and productivity increases to bring about improvement. The small-scale farmers registered only 54 per cent with improved dietary conditions, compared to 81 , 79 and 85 per cent of lower-medium, upper-medium, and large farmers respectively. The larger the farm, the better the improvements in nutrition are, as the commercial crops grown are also food crops, while increasing income from sales also enables purchases of protein from markets which are well-served due to the improved transportation systems.

In terms of location, most farmers (about 80 per cent) in the upper-east region had improved dietary conditions

Table 6.3: Improved dietary conditions by farm scales

\begin{tabular}{|l|l|l|l|l|l|l|}
\hline & \multicolumn{2}{|c|}{ Yes } & \multicolumn{2}{c|}{ Remained unchanged } \\
\hline Scale of farmer & Frequency & $\%$ & Frequency & $\%$ & Frequency & $\%$ \\
\hline Small & 85 & 54.5 & 48 & 30.8 & 23 & 14.7 \\
\hline Lower-medium & 100 & 81.3 & 14 & 11.4 & 9 & 7.3 \\
\hline Upper-medium & 11 & 78.6 & 1 & 7.1 & 2 & 14.3 \\
\hline Large & 6 & 85.7 & 1 & 14.3 & 0 & 0.0 \\
\hline Total & $\mathbf{2 0 2}$ & & $\mathbf{6 4}$ & & $\mathbf{3 4}$ & \\
\hline
\end{tabular}

Source: Authors' own (survey data, 2020)

Table 6.4: Improved dietary conditions by location (region)

\begin{tabular}{|l|l|l|l|l|l|l|}
\hline & \multicolumn{2}{|c|}{ Yes } & \multicolumn{3}{c|}{ Remained unchanged } \\
\hline Region & Frequency & $\%$ & Frequency & $\%$ & \multicolumn{3}{c|}{ Frequency } & $\%$ \\
\hline Northern & 84 & 56.0 & 48 & 32.0 & 18 & 12.0 \\
\hline Upper-east & 118 & 78.7 & 16 & 10.7 & 16 & 10.7 \\
\hline Total & $\mathbf{2 0 2}$ & & $\mathbf{6 4}$ & & $\mathbf{3 4}$ & \\
\hline
\end{tabular}

Source: Authors' own (survey data, 2020) compared to the northern region (about 56 per cent), with a third not recording any improvements (see Table 6.4). In terms of gender, there were no significant differences between male and female farmers in both regions. The operation of the different diversified farming systems in the Builsa area, coupled with a huge supply of fish protein and local poultry production in the Fumbisi area, explains this state. Compound farms are still very effective in meeting the food needs of the poor small farmers compared to places without these. 


\section{DISCUSSION AND CONCLUSIONS}

This paper has provided plausible explanations for the rising farm sizes, the nature of the relations between socially differentiated farmers, and the livelihood outcomes of these farmers by examining the case of two districts in northern Ghana. Northern Ghana is experiencing a silent agricultural revolution with rapid transformations that seem to be more sustainable than in the past. The struggle to modernise agriculture dates to the immediate post-independence era, but with mixed successes. The current momentum is a continuation of these earlier state efforts which are occurring when certain favourable conditions are now in place for a more sustained revolution. The process of agricultural transformation has been characterised by changes in farm sizes and increasing usage of modern inputs involving commercialised transactions. Increasing farm sizes are associated with changes in land and labour relations within and outside households and communities; changes in technologies used in farming, especially mechanisation for ploughing, harvesting, and processing; herbicides and weedicides for farm preparation and weed control; fertilisers for increasing soil fertility; and pesticides/fungicides for the control of pests and diseases. Is it the case that state efforts have paid off, or the case that the right mediating variables - such as rising urban populations, global market supply constraints supported by local market opportunities, improvements in infrastructure and general enlightenment among the rural population - have catalysed the transition to modern, mediumscale, commercialised agriculture?

Generally, the drivers for the increasing farm sizes first derive from the fact that vast uncultivated lands exist in the area. A substantial increase in the ownership and rental of mechanisation equipment has enabled even the smallest farmer the possibility of doubling farm sizes in the last two decades. The use of herbicides and weedicides solves the problem of labour for preparing and weeding a farm, but comes at the cost of adopting mono-cropping regimes which lead to farmers cultivating many farms. The choice of crops is purely on a commercial ethos, as the size of farms are above what is needed for subsistence. The improvements in communication and transport infrastructure facilitate the availability of information and the reach of markets for farm produce. Increasing productivity to increase profitability of farming is aided by improved seeds, which are most popular among more commercialised farmers who also own larger farms. The drivers of the increasing farm sizes outlined in this study emanate from the role of the state in agricultural modernisation through decades of policy interventions. For northern Ghana's agriculture, which is mainly a food crop producer, neoliberal globalisation has not been a driver but an enemy, hence problems with global food supply chains play well into the growth of northern agricultural modernisation. This buttresses analysis by Havnevik et al. (2007) of the deleterious nature of neoliberal globalisation propagated by the World Bank for food crop production in poor African countries. Amanor (2019) also argues that contemporary medium-scale farmers and farming areas bear similar features with those of the 1970s, showing the importance of the continuity of historical processes under the right conditions rather than being the result of only new processes.

Who are the winners and losers of these processes, and what political economy processes and factors are responsible? There is a tendency to set aside the socioeconomic aspects of the process of modernisation of agriculture, which has implications for the wellbeing of all in society. The emerging relations of production between the different categories of farmers is critical to ensure a balanced development effort with possibilities for all in society to achieve income growth, and food and nutritional security. On the synergistic side, there have been positive spill-over effects between smaller and bigger farmers through reciprocal exchanges of labour, local knowledge, capital, and new technologies. The success of small farmers in scaling up farming is due mainly to mechanisation services and wage income from bigger farmers, while richer, less knowledgeable urban farmers have benefitted from the advice and skilled labour of smaller farmers. The political influence of richer farmers has also resulted in general community benefits involving infrastructure provision and other political allocations, which would not have been provided to a purely smallholder farming community. These findings are similar to those of several researchers in other African countries (Muyanga et al., 2019; Liverpool-Tasie et al., 2020). 
However, the contradictions of the increasing farm sizes and technological innovation diffusion are notable and need attention. The process is culminating in a landscape of losers and winners, as land is allocated to those who reward custodians of land; input dealers become richer due to dependency of farmers on external inputs; big farmers benefit more from their relations with smaller farmers by exploiting the latter's labour and their receipt of rents from mechanisation services and loans. Several authors show how small farmers are largely the losers in these relations, and argue for a careful analysis of socially differentiated effects of agrarian change (Chamberlin and Jayne, 2020; Lay, Nolte and Sipangule, 2021). Household relations of production are changing as individual members are no longer too dependent on the head for land and other support, thereby breaking down social systems and generally reorienting traditional relations in favour of a more commercialised, non-communitarian one. The unending struggles between capital and labour have shaped agricultural development over time, as noted also by van Hear (1984). The age-old debate as espoused by Johnston and Kilby (1992) outlining unimodal and bimodal strategies of agrarian development needs revisiting, as this study shows the importance of interdependence, synergy and contradictions which needs careful negotiating rather than sticking to binaries.

The position of women in these processes is worrying, as many are unable to join the most rewarding segments of the transition. Fewer women are increasing the size of their farms significantly, and for most it is at a slower rate of increase than men. Information flow on modern technologies is lower for women due to patriarchal systems which are still stronger on women than younger men. The only way women can join their male counterparts on an equal note is if they are rich, because the new commercialised norms respect the rich to whom all courtesies are accorded, irrespective of gender. Unfortunately, many rural women are poor, and depend on their brothers and husbands for access to productive resources (Apusigah, Tsikata, and Mukhopadyay, 2011; Torvikey, 2021). Improving access to land, capital and markets would go a long way to boost women's empowerment in the area (Millar, 2015; Lanz, Prügl and Gerber, 2020).

The increasing farm sizes, especially involving the majority of farmers stepping up through increasing acreages, is welcome news. The development models experimented by various donors have revolved around the use of anchor farmers for innovation diffusion of late. The current process fits well into that doctrine, as a few farmers are found in the upper-medium and large-scale categories who possess the modern equipment and capital to carry out modern farming recommendations. These farmers who are stepping in have the political and market connections, and the capital needed, to purchase technologies needed for the modernisation of agriculture to be emulated by their smaller poorer counterparts, albeit imperfectly. A few farmers, however, are unable to join this transition, and therefore form the hanging in and dropping out group, who outmigrate or provide services to the thriving farmers in the form of labour. Modern technologies seem not to have resolved the problems of farming in a semi-arid zone as climate change, and market failures continue to plague all categories of farmers. Also, as noted by Kansanga et al. (2019), a mechanisation paradox is emerging as farm sizes expand. The shift in cropping patterns from traditional crops to market-oriented crops involves predominantly mono-cropping systems which, we argue, have mixed outcomes of generating more incomes for some farmers while worsening food security problems for those less commercialised with smaller farms. The study shows that localities with compound farms, which mainly provide food crops for household consumption, tend to have better food security than those concentrating mostly on valley and upland commercialised systems, thereby underscoring the need to encourage households to prioritise fields for their own consumption, too.

This study shows that the post-structural adjustment processes of accumulation by farmers are more favourable compared to the conclusion reached by Whitehead (2002) two decades ago that climate change, government economic policy which centred on adjustment measures, and changes in the local and national markets for labour and products created a highly constrained and unpredictable environment for individuals and households. To propel the agricultural revolution ongoing in northern Ghana, it is necessary to enhance and support beneficial relations among different categories of farmers while reducing the contradictions and tensions emerging from these relations. An African green revolution is really within reach if the right mechanisms are in place, as emphasised by Ejeta (2010). The state needs to revise its role in facilitating the availability of technological inputs to farmers through smart subsidies; building implement fabrication and training centres and linking local fabricators to more advanced counterparts in a South-South cooperation framework; dealing with mechanisms to regulate land allocation and subsequent security of tenure; and through the extension services, improve innovation diffusion of both traditional and modern practices; and tackle environmental pollution due to increasing agro-chemical use. Certainly, the rising farm sizes have improved food security for households and ensured many can meet the increasing 
cost of living. Serious efforts should, therefore, be made to enable all farmers to go beyond subsistence, while limiting excessive land grabbing that may negate the transformational agenda. Beyond the extensification drive is the need to intensify production on existing lands, which may benefit the small farmer relatively more with implications for a broader welfare for most of the rural population. 
Amanor, K.S. (2019) Mechanised Agriculture and Medium-Scale Farmers in Northern Ghana: a Success of Market Liberalism or a Product of a Longer History? APRA Working Paper 23. Brighton: Future Agricultures Consortium. Available at: https://opendocs.ids.ac.uk/opendocs/handle/20.500.12413/14433 (Accessed: 15 January 2021).

Amanor, K.S. and Pabi, O. (2007) 'Space, time, rhetoric and agricultural change in the transition zone of Ghana', Human Ecology, 35: 51-67.

Apusigah, A.A., Tsikata, D. and Mukhopadyay, M.M. (2011). Women's Rights Organizations and Funding Regimes in Ghana. Accra: CEGENSA and Pathways of Women's Empowerment.

Braimoh, A.K. (2009) 'Agricultural land-use change during economic reforms in Ghana', Land Use Policy, 26: 763-771.

Burke, W.J., Jayne, T.S. and Sitko, N.J. (2020) 'Do medium-scale farms improve market access conditions for Zambian smallholders?', Journal of Agricultural Economics 71: 517-533.

Chamberlin, J. and Jayne, T. (2020) 'Does farm structure affect rural household incomes? Evidence from Tanzania', Food Policy 90: 101805.

Chambers, R. (2014) Rural development: Putting the last first. London: Routledge.

Deininger, K. and Byerlee, D. (2012) 'The Rise of Large Farms in Land Abundant Countries: Do They Have a Future?', World Development 40(4): 701-714.

Deininger, K., Byerlee, D., Lindsay, J., Norton, A., Selod, H. and Stickler, M. (2011) Rising Global Interest in Farmland: Can it Yield Sustainable and Equitable Benefits? Agriculture and Rural Development. Washington DC: World Bank

Dickson, K.B. (1968) 'Background to the problem of economic development in Northern Ghana', Annals of the Association of American Geographers 58: 686-696.

Due, J.M. (1969) 'What Has Happened to the Ghanaian State Farms?', Illinois Agricultural Economics 9: 25-35.

Gyasi, E. (1996) 'The environmental impact and sustainability of plantations in sub-Saharan Africa: Ghana's experiences with oil-palm plantations', in E. Gyasi and J. Uitto (eds.), Sustaining the future: Economic, social, and Environmental change in Sub-Saharan Africa. Tokyo: United Nations University Press.

Hägerstrand, T. (1968) Innovation diffusion as a spatial process. Chicago: University of Chicago Press.

Havnevik, K., Bryceson, D., Birgegård, L.-E., Matondi, P. and Beyene, A. (2007) African agriculture and the World Bank: development or impoverishment? Nordiska Afrikainstitutet.

Houssou, N., Johnson, M., Kolavalli, S. and Asante-Addo, C. (2016) Changes in Ghanaian farming systems stagnation or a quiet transformation? IFPRI Discussion Paper 01504. Washington DC: International Food Policy Research Institute.

Houssou, N., Johnson, M., Kolavalli, S. and Asante-Addo, C. (2018) 'Changes in Ghanaian farming systems: stagnation or a quiet transformation?', Agriculture and Human Values 35: 41-66.

Jayne, T.S., Chamberlin, J. and Headey, D.D. (2014) 'Land pressures, the evolution of farming systems, and development strategies in Africa: A synthesis', Food Policy 48: 1-17. 
Jayne, T.S., Chamberlin, J., Traub, L., Sitko, N., Muyanga, M., Yeboah, F.K., Anseeuw, W., Chapoto, A., Wineman, A. and Nkonde, C. (2016) 'Africa's changing farm size distribution patterns: the rise of medium-scale farms', Agricultural Economics 47: 197-214.

Jayne, T.S., Chapoto, A., Sitko, N., Nkonde, C., Muyanga, M. and Chamberlin, J. (2014) 'Is the scramble for land in Africa foreclosing a smallholder agricultural expansion strategy?', Journal of International Affairs 67(2): 35-53.

Jayne, T.S., Muyanga, M., Wineman, A., Ghebru, H., Stevens, C., Stickler, M., Chapoto, A., Anseeuw, W., Van Der Westhuizen, D. and Nyange, D. (2019) 'Are medium-scale farms driving agricultural transformation in subSaharan Africa?', Agricultural Economics 50: 75-95.

Johnston, B.F. and Kilby, P. (1992) 'Unimodal' and 'bimodal' strategies of agrarian change', in J. Harris (ed.), Rural development: theories of peasant economy and agrarian change. London: Routledge.

Johnston, F.B. and Mellor, W. J. (1961) 'The Role of Agriculture in Economic Development', The American Economic Review 51: 566-593.

Kansanga, M., Andersen, P., Kpienbaareh, D., Mason-Renton, S., Atuoye, K., Sano, Y., Antabe, R. and Luginaah, I. (2019) 'Traditional agriculture in transition: examining the impacts of agricultural modernization on smallholder farming in Ghana under the new Green Revolution', International Journal of Sustainable Development and World Ecology 26: 11-24.

Kasanga, R.K. (1995) 'Land tenure and regional investment prospects: the case of the tenurial systems of Northern Ghana', Property Management 13: 21-31.

Konings, P. (1981) Peasantry and state in Ghana: the example of the Vea irrigation project in the upper region of Ghana. ASC Working Paper Series. Leiden: African Studies Centre.

Konings, P. (1984) 'Capitalist rice farming and land allocation in Northern Ghana', The Journal of Legal Pluralism and Unofficial Law 16: 89-119.

Lanz, K., Prügl, E. and Gerber, J.-D. (2020) 'The poverty of neoliberalized feminism: Gender equality in a 'best practice'large-scale land investment in Ghana', The Journal of Peasant Studies 47: 525-543.

Lay, J., Nolte, K. and Sipangule, K. (2018) Large-scale farms and smallholders: Evidence from Zambia. GIGA Working Papers, No. 310. Hamberg: German Institute of Global and Area Studies (GIGA), Hamburg

Lay, J., Nolte, K. and Sipangule, K. (2021) 'Large-scale farms in Zambia: Locational patterns and spillovers to smallholder agriculture', World Development 140: 105277.

Liverpool-Tasie, L.S.O., Nuhu, A.S., Awokuse, T., Jayne, T., Muyanga, M., Aromolaran, A. and Adelaja, A. (2020) Spillover Effects of Medium-Scale Farms on Smallholder Behaviour and Welfare: Evidence from Nigeria. APRA Working Paper 38. Brighton: Future Agricultures Consortium. Available at: https://opendocs.ids.ac.uk/opendocs/ handle/20.500.12413/15712 (Accessed: 2 March 2021).

Lowder, S.K., Skoet, J. and Raney, T. (2016) 'The number, size, and distribution of farms, smallholder farms, and family farms worldwide', World Development 87: 16-29.

Masters, W.A., Djurfeldt, A.A., De Haan, C., Hazell, P., Jayne, T., Jirström, M. and Reardon, T. (2013) 'Urbanization and farm size in Asia and Africa: Implications for food security and agricultural research', Global Food Security 2: $156-165$.

Mellor, J.W. (1976) The new economics of growth; a strategy for India and the developing world. Ithaca: Cornell University Press.

Millar, G. (2015) '“We have no voice for that”: Land rights, power, and gender in rural Sierra Leone', Journal of Human Rights 14: 445-462.

Ministry for Food and Agriculture (2015) Agriculture in Ghana: Facts and figures. Accra: Statistics, Research, and Information Directorate of the Ministry of Food and Agriculture. 
Muyanga, M., Aromolaran, A., Jayne, T., Liverpool-Tasie, S., Awokuse, T. and Adelaja, A. (2019) Changing Farm Structure and Agricultural Commercialisation in Nigeria. APRA Working Paper 26. Brighton: Future Agricultures Consortium. Available at: https://opendocs.ids.ac.uk/opendocs/handle/20.500.12413/14576 (Accessed: 20 June 2020).

Omotilewa, O.J., Jayne, T.S., Muyanga, M., Aromolaran, A.B., Liverpool-Tasie, L.S.O., and Awokuse, T. (2021). 'A revisit of farm size and productivity: Empirical evidence from a wide range of farm sizes in Nigeria', World Development 146: 105592.

Rodenburg, J., Johnson, J.-M., Dieng, I., Senthilkumar, K., Vandamme, E., Akakpo, C., Allarangaye, M.D., Baggie, I., Bakara, S.O., Bam, R.K., Bassoro, I., Abera, B.B., Cisse, M., Dougbe, W., Gbakatchétché, H., Jaiteh, F., Kajiru, G.J., Kalisa, A., Kamissoko, N., Sékou, K., Kokou, A., Mapiemfu-Lamare, D., Lunze, F.M., Mghase, J., Maïga, I.M., Nanfumba, D., Niang, A., Rabeson, R., Segda, Z., Sillo, F.S., Tanaka, A. and Saito, K. (2019). 'Status quo of chemical weed control in rice in sub-Saharan Africa', Food Security 11(1): 69-92.

Sitko, N.J. and Chamberlin, J. (2016) 'The geography of Zambia's customary land: Assessing the prospects for smallholder development', Land Use Policy 55: 49-60.

Smalley, R. (2013) Plantations, contract farming and commercial farming areas in Africa: A comparative review. FAC Working Paper 55. Brighton: Future Agricultures Consortium. Available at: http://www.fao.org/uploads/ media/FAC_Working_Paper_055.pdf (Accessed: 15 July 2016).

Songsore, J. (1979) Structural crisis, dependent capitalist development and regional inequality in Ghana. Report No. 71. The Hague: International Institute of Social Studies.

Sutton, I. (1989) 'Colonial agricultural policy: The non-development of the Northern Territories of the Gold Coast', The International Journal of African Historical Studies 22: 637-669.

Teye, J.K. and Nikoi, E. (2021) The political economy of the cocoa value chain in Ghana. APRA Working Paper 53. Brighton: Future Agricultures Consortium. Available at: https://opendocs.ids.ac.uk/opendocs/ handle/20.500.12413/16676 (Accessed: 17 July 2021).

Torvikey, G.D. (2021) 'Land, Gender, and Class Relations in Ghana's Cassava Frontier', Agrarian South: Journal of Political Economy 10: 139-154.

Van Hear, N. (1984) 'By-day' boys and dariga Men: casual labour versus Agrarian capital in Northern Ghana', Review of African Political Economy 11: 44-56.

Vercillo, S. and Hird-Younger, M. (2019) 'Farmer resistance to agriculture commercialisation in northern Ghana', Third World Quarterly 40: 763-779.

Wahab, I. (2020) A bird's eye-view of smallholder productivity: Current measurement shortfalls, farmer perceptions and rationality on rainfed family farms in Ghana. Doctoral Dissertation, Lund University.

Whitehead, A. (2002) 'Tracking Livelihood Change: Theoretical, Methodological and Empirical Perspectives from North-East Ghana', Journal of Southern African Studies 28: 575-598.

Yaro, J.A. (2012) 'Re-inventing traditional land tenure in the era of land commoditization: some consequences in periurban northern Ghana', Geografiska Annaler: Series B, Human Geography 94: 351-368.

Yaro, J. A., Teye, J.K. and Torvikey, G.D. (2018) 'Historical context of agricultural commercialisation in Ghana: Changes in land and labour relations', Journal of Asian and African Studies 53: 49-63. 
Yaro, J.A., Wahab, I., Afful-Mensah, G. and Awenam, M.B. (2021) The Drivers of Medium-Scale Farms and the Emerging Synergies and Contradictions Among Socially Differentiated Farmers in Northern Ghana, APRA Working Paper 71, Brighton: Future Agricultures Consortium

(c) APRA 2021

ISBN: 978-1-78118-861-3

DOI: 10.19088/APRA.2021.030

\section{(cc) BY-NC-ND}

This is an Open Access report distributed under the terms of the Attribution-Non Commercial-No Derivs 4.0 Unported (CC BY-NC-ND 4.0) Attribution - You must give appropriate credit, provide a link to the license, and indicate if changes were made. You may do so in any reasonable manner, but not in any way that suggests the licensor endorses you or your use. NonCommercial — You may not use the material for commercial purposes. NoDerivatives - If you remix, transform, or build upon the material, you may not distribute the modified material. You are free to: Share - copy and redistribute the material in any medium or format.

https://creativecommons.org/licenses/by-nc-nd/4.0/legalcode

If you use the work, we ask that you reference the APRA website (www.future-agricultures.org/apra/) and send a copy of the work or a link to its use online to the following address for our archive: APRA, Future Agricultures Consortium, University of Sussex, Brighton BN1 9RE, UK (apra@ids.ac.uk)

All APRA Working Papers go through a review process before publication.

\section{@creative}

\section{DO YOU HAVE COMMENTS ON THIS PAPER?}

We would welcome your feedback on this working paper!

To provide brief comments, please follow this link to our short APRA Working Paper Feedback form: https://goo.gl/forms/1iVnXhhrlGesfR9

Agricultural Policy Research in Africa (APRA) is a programme of the Future Agricultures Consortium (FAC) which is

generating new evidence and policy-relevant insights on more inclusive pathways to agricultural commercialisation in sub-Saharan Africa. APRA is funded with UK aid from the UK Foreign, Commonwealth \&

Development Office (FCDO) and will run from 2016-2022.

The APRA Directorate is based at the Institute of Development Studies (IDS), UK (www.ids.ac.uk), with regional hubs at the Centre for African Bio-Entrepreneurship (CABE), Kenya, the Institute for Poverty, Land and Agrarian Studies (PLAAS), South Africa, and the University of Ghana, Legon. It builds on more than a decade of research and policy engagement work by the Future Agricultures Consortium (www.future-agricultures.org) and involves more than 100 researchers and communications professionals in Africa, UK, Sweden and USA. 